\title{
Half-Sandwich Ir(III) and Os(II) Complexes of Pyridyl-Mesoionic Carbenes as Potential Anticancer Agents
}

\author{
Juran Kralj, ${ }^{\dagger, \#}$ Aljoša Bolje, ${ }^{\ddagger}, \#$ Darija Stupin Polančec, ${ }^{\S}$ Ivana Steiner, ${ }^{\dagger}$ Tena Gržan, ${ }^{\dagger}$ Ana Tupek, \\ Nikolina Stojanović, ${ }^{\dagger}$ Stephan Hohloch, ${ }^{\| \odot}$ Damijana Urankar, ${ }^{\ddagger}$ Maja Osmak, ${ }^{\dagger}$ Biprajit Sarkar, ${ }^{*}, \|^{\circ}$ \\ Anamaria Brozovic, ${ }^{*}, \dagger$ and Janez Košmrlj*, \\ ${ }^{\dagger}$ Division of Molecular Biology, Ruđer Bošković Institute, HR-10000 Zagreb, Croatia \\ ${ }^{\ddagger}$ Faculty of Chemistry and Chemical Technology, University of Ljubljana, Večna pot 113, SI-1000 Ljubljana, Slovenia \\ ${ }^{\S}$ Fidelta Ltd., HR-10000 Zagreb, Croatia \\ "Institut für Chemie und Biochemie, Freie Universität Berlin, Fabeckstraße 34-36, D-14195 Berlin, Germany
}

Supporting Information

ABSTRACT: A series of cationic chlorido arene-iridium(III) and arene-osmium(II) complexes with bidentate pyridyl functionalized mesoionic carbenes (MIC) of the 1,2,3triazol-5-ylidene type have been prepared. The variations in the ligand structures include the position of the pyridyl substituent relative to the triazolylidene ring ( $\mathrm{N}$-wingtip vs $\mathrm{C}$ wingtip), phenyl versus ethyl substituents, and incorporation of several functional groups at the phenyl substituents. Five

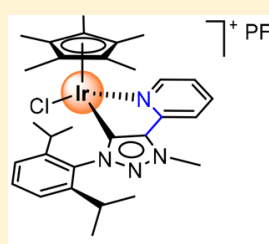

$\mathrm{IC}_{50}(\mathrm{HeLa})=2.0 \mu \mathrm{M}$

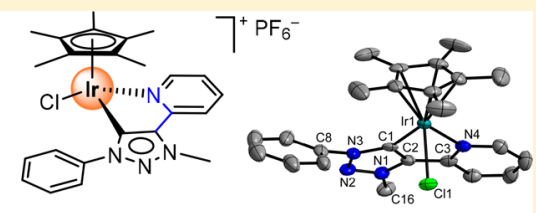

$\mathrm{IC}_{50}(\mathrm{HeLa})=7.3 \mu \mathrm{M}$ complexes have been characterized by X-ray structural analysis. All complexes, including osmium(II) and ruthenium(II) analogues having a pyrimidyl in place of the pyridyl group, have been studied for their cytotoxic activity on a human cervical carcinoma HeLa cell line. Two of the compounds, $\mathbf{I r}^{\mathbf{5}}$ and $\mathbf{I r}^{\mathbf{9}}$, were the most cytotoxic with $\mathrm{IC}_{50}$ values of $7.33 \mu \mathrm{M}$ and 2.01 $\mu \mathrm{M}$, respectively. Examination of their cytotoxic effect on different cell lines revealed that they preferentially kill cancer over normal cells. The $\mathbf{I r}^{5}$ and $\mathbf{I r}^{9}$ compounds arrested cells in G2 and induced a dose-dependent increase in SubG0/G1 cell population. Apoptosis, as the primary mode of cell death, was confirmed by Annexin V/PI staining, detection of cleaved PARP, and caspases 3 and 7 activity upon treatment of HeLa cells with both compounds. The higher toxicity of $\mathbf{I r}^{9}$ is probably due to its increased accumulation in the cells compared to $\mathbf{I r}^{\mathbf{5}}$. The role of glutathione (GSH) in the protection of cells against $\mathbf{I r}^{5}$ and Ir $^{9}$ cytotoxicity was confirmed by pretreatment of cells either with buthionine sulfoximine (inhibitor of GSH synthesis) or Nacetyl-cysteine (precursor in GSH synthesis).

\section{INTRODUCTION}

Cancer is one of the leading causes of death worldwide, treated mostly by surgery, radiotherapy, and chemotherapy. ${ }^{1}$ Despite a broad use of well-known metal-based anticancer drugs, such as cisplatin and its derivatives, two main disadvantages of chemotherapy remain a problem in successful treatment of a variety of tumor types. Chemotherapeutics are largely inefficient against drug-resistant tumors and are followed by severe side effects including nephrotoxicity, hepatotoxicity, ototoxicity, and cardiotoxicity. ${ }^{2}$ This urges a need for investigation of new compounds that will be highly toxic against tumor cells and nontoxic for the healthy cell population.

Recently, organometallic compounds have gained interest as anticancer agent candidates, owing to their increased structural variety, diverse stereochemistry, and modular way of ligand selection compared to organic molecules. Despite possessing a carbon-metal bond, these compounds are often kinetically stable, uncharged, and relatively lipophilic. Their metal atoms can be in a low oxidation state, making them suitable for application in medicinal chemistry. ${ }^{3}$
Mesoionic carbenes (MIC) of the 1,2,3-triazol-5-ylidene type are currently highly popular ligands in organometallic chemistry. ${ }^{4,5}$ Apart from the fact that their use as a ligand class is barely 10 years old, an important reason for their popularity is their modular synthesis by Click-reaction. Thus, introducing additional heteroatom donors on such ligands and tuning of the steric and electronic properties is often easier compared to the most other classes of N-heterocyclic carbenes (NHC). Hence, metal complexes of such ligands were successfully used in a variety of homogeneous catalytic processes. Additionally, metal complexes of these ligands have been successfully investigated for their intriguing redox properties, such as electrocatalysts, and for their photochemical properties. One field of research, where metal complexes of MICs are slowly but surely displaying promise, is their potential use in anticancer research. ${ }^{5,6}$ This is perhaps not that surprising considering the potential that metal complexes of various other NHC ligands have shown in medicinal chemistry. Recently, we

Received: May 15, 2019

Published: October 9, 2019 
Scheme 1. Synthesis of $\mathrm{Os}(\mathrm{II})$, Ir(III), and Ru(II) Complexes
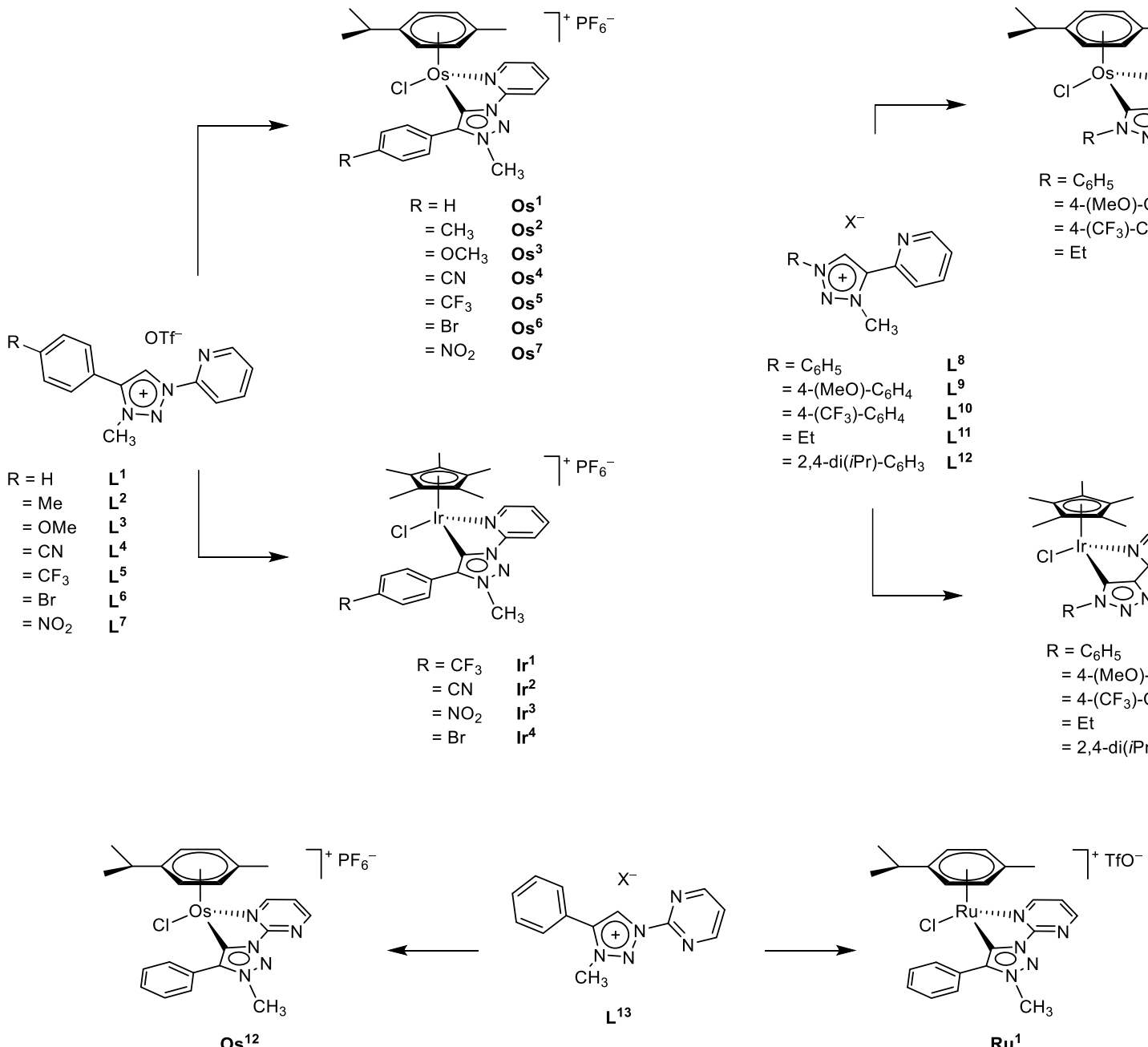

$\mathrm{Ru}^{1}$ have shown that 1,2,3-triazolium salts, precursor for the 1,2,3triazol-5-ylidene MIC ligands, also possess anticancer activity. ${ }^{7}$

In the past years, we have been involved in the synthesis of pyridyl-substituted MIC ligands and their metal complexes, which are potent catalysts for a variety of homogeneous catalytic processes. ${ }^{8}$ An important discovery in terms of ligand synthesis was the development of methodologies for selective alkylation of pyridyl-triazoles.' Herein, we report on the synthesis of a series of Os(II) and Ir(III) complexes, as well as one $\mathrm{Ru}(\mathrm{II})$ analogue with pyridyl-MICs. We present a comprehensive study involving 12 Os(II), 8 Ir(III) complexes, and $1 \mathrm{Ru}(\mathrm{II})$ complex, along with their cytotoxic properties. The effects of introduced ligands and metal centers on cytotoxic properties as well as their mechanisms of action in cells are discussed.

\section{RESULTS AND DISCUSSION}

Synthesis and Characterization. The ligand precursors, triazolium salts, were synthesized following procedures that were recently reported by us.,10 The variations in ligand precursor structures of $\mathbf{L}^{1}-\mathbf{L}^{12}$ include the position of the pyridyl substituent ( $\mathrm{N}$ vs $\mathrm{C}$-wingtip of the triazolylidene ring), phenyl versus ethyl substituents, and incorporation of several functional groups on the phenyl substituents (Scheme 1). Triazole rings in $\mathbf{L}^{1}-\mathbf{L}^{7}$ are characterized by the N1-pyridyl substituent (N-wingtip), whereas those in $\mathbf{L}^{8}-\mathbf{L}^{12}$ have the chelating pyridine at C5 (C-wingtip). Ligand precursors $\mathbf{L}^{\mathbf{1}}$ $\mathrm{L}^{12}$ were used for the synthesis of osmium(II) $\left(\mathbf{O s}^{1}-\mathbf{O} \mathbf{s}^{12}\right)$ and iridium(III) half-sandwich complexes $\left(\mathbf{I r} \mathbf{r}^{1}-\mathbf{I} \mathbf{r}^{9}\right)$. Transmetalation protocol ${ }^{8}$ with $\mathrm{Ag}_{2} \mathrm{O}$ turned out to be the route of choice affording the products from moderate $50 \%$ yields to higher. Additionally, in the particular case of ligand precursor $\mathbf{L}^{\mathbf{1 3}}$, pyrimidyl was used as a heterocycle ( $\mathrm{N}$-wingtip) instead of pyridyl to construct complexes $\mathbf{O} \mathbf{s}^{\mathbf{1 2}}$ and $\mathbf{R} \mathbf{u}^{\mathbf{1}}$.

The complexes were characterized via ${ }^{1} \mathrm{H}$ and ${ }^{13} \mathrm{C}$ NMR spectroscopy and mass spectrometry. The disappearance of the signal corresponding to the triazolium $\mathrm{C}-\mathrm{H}$ proton in the ${ }^{1} \mathrm{H}$ NMR spectrum of the complexes was already a first indication of the formation of the complexes. In the ${ }^{13} \mathrm{C}$ NMR spectra, the peak corresponding to the metal-bound MIC-C was observed between 159.6 and $160.9 \mathrm{ppm}$ for the Os(II) complexes and between 156.3 and 158.4 ppm for the $\operatorname{Ir}(\mathrm{III})$ complexes. Molecular peaks corresponding to the cations were observed for all the complexes in their HRESI mass spectra.

Crystal Structures. We were successful in obtaining single crystals of compounds $\mathbf{O s}^{8}, \mathbf{O s}^{11}, \mathbf{I r}^{5}, \mathbf{I r}^{6}$, and $\mathbf{I r}^{7}$ that were suitable for $\mathrm{X}$-ray diffraction studies (Figure 1). The two osmium complexes and $\mathbf{I r}^{\mathbf{6}}$ crystallized as dichloromethane solvates. All the metal centers were coordinated in a pianostool type of coordination. The $\mathrm{Cp}^{*}$ ligands were bound in an $\eta^{5}$ way to the $\operatorname{Ir}(\mathrm{III})$ centers, and the cymene ligands were bound in an $\eta^{6}$ fashion to the Os(II) centers. The three "legs" 

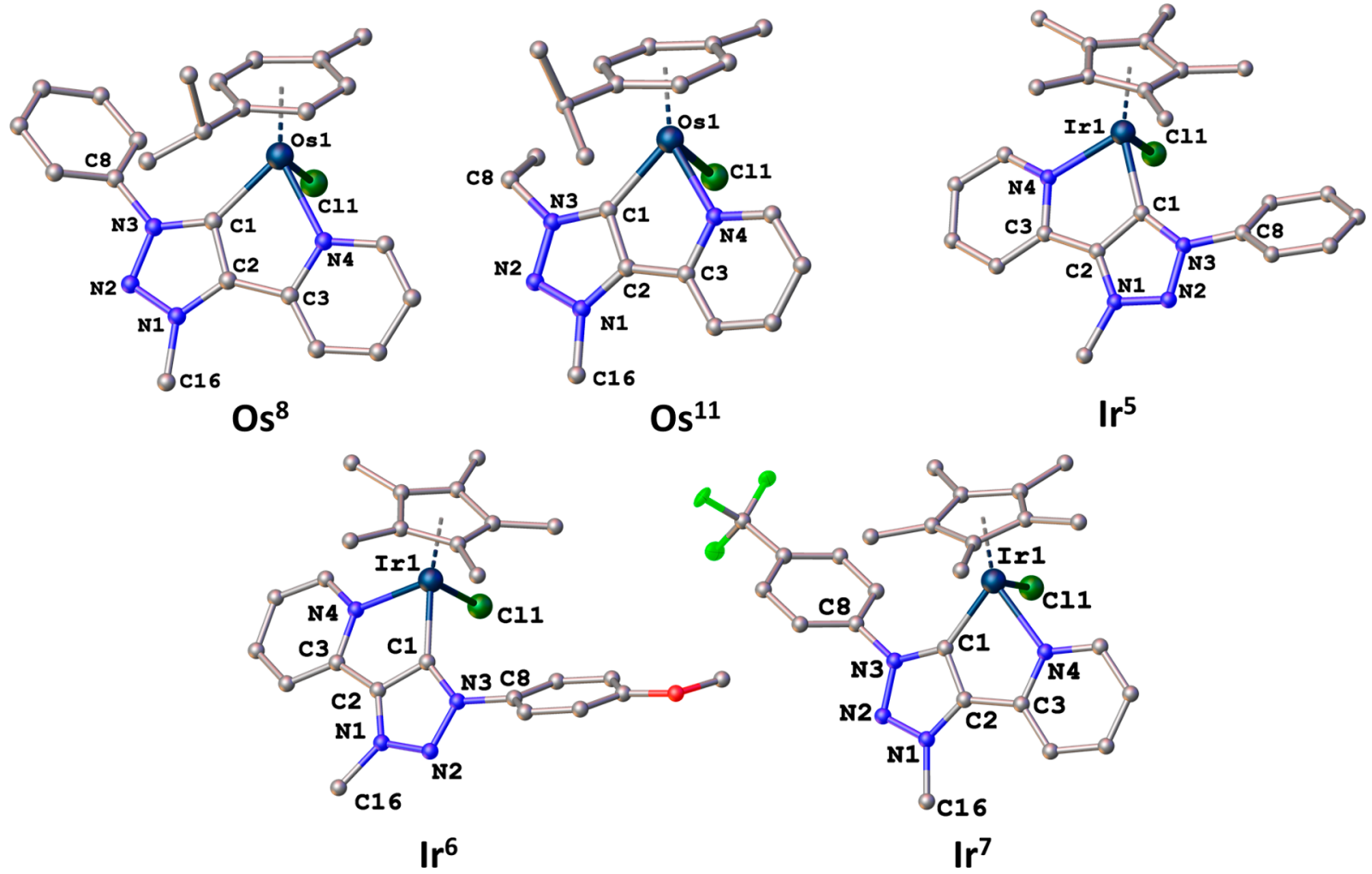

Figure 1. Ball and stick models of $\mathbf{O} \mathbf{s}^{8}, \mathbf{O s}^{11}, \mathbf{I r} \mathbf{r}^{5}, \mathbf{I r}^{6}$, and $\mathbf{I r} \mathbf{r}^{7}$. Hydrogen atoms, counterions, and solvent molecules are omitted for clarity. Selected bond lengths and angles are reported in Table 1.

of the piano-stool are then made up of the pyridyl-N and MIC$\mathrm{C}$ of the chelating ligands and an additional chloride ligand. As it has been observed earlier, the bond lengths inside the triazolylidene rings point to a delocalized situation (Table 1). The metal-C(MIC) and the metal- $N$ (pyridine) distances are all in the expected range. ${ }^{4 c, e, f}$ The aryl substituents on the triazolylidene rings are twisted out of plane as seen from angles close to $50^{\circ}$ between the two rings (Table 1 ).

Effect of the Complexes on Cell Viability. This work was stimulated by recent reports on cytotoxic properties of the ligand precursors, 1,2,3-triazolium salts, ${ }^{7}$ as well as organometallic compounds of triazolylidene structure. ${ }^{5,6}$ Some triazolium salts exhibited high cell-type dependent cytotoxicity against different tumor cells. Those did not bind double stranded DNA, but induced formation of reactive oxygen species, which further triggered cell death. ${ }^{7}$ An excellent activity profile against a range of cell lines has been shown for half-sandwich $\mathrm{Ru}(\mathrm{II})$ and $\mathrm{Os}(\mathrm{II})$ organometallics having triazolylidene as a monodentate MIC ligand. ${ }^{6 a}$ The structures of the half-sandwich $\mathrm{Os}(\mathrm{II}), \mathrm{Ir}(\mathrm{III})$, and $\mathrm{Ru}(\mathrm{II})$ compounds $\mathbf{O s}{ }^{1}-\mathbf{O s}{ }^{12}, \mathbf{I r}^{1}-\mathbf{I r}^{9}$, and $\mathbf{R} \mathbf{u}^{1}$ are distinctly different from the compounds mentioned above, possessing bidentate pyridyltriazolylidene ligand that chelates the metal in $N$ (pyridine) ${ }^{\wedge} C(\mathrm{MIC})$ mode. In $\mathbf{O} \mathbf{s}^{\mathbf{1 2}}$ and $\mathbf{R} \mathbf{u}^{1}$ the pyridyl dent is replaced by pyrimidyl.

First, all the complexes were evaluated for their cytotoxicity potential on human cervical carcinoma ( $\mathrm{HeLa}$ ) cells, the cell model system that was previously identified as suitable for the screening of new compounds. ${ }^{11,12}$ The results of the screening are collected in Table 2 .

Cytotoxicity of complexes $\mathbf{O s}^{1}, \mathbf{O s}^{3}-\mathbf{O s}^{5}, \mathbf{O s}^{7}, \mathbf{O s}^{8}, \mathbf{O s}^{11}$, $\mathbf{I r}^{1}-\mathbf{I r}^{3}, \mathbf{I r}^{\mathbf{8}}$, and $\mathbf{R \mathbf { u } ^ { 1 }}$ could not be determined due to their poor solubility. Compound $\mathbf{I r}^{9}$ with $\mathrm{IC}_{50}$ of $2.01 \mu \mathrm{M}$ was the
Table 1. Bond Lengths (̊̊), Angles, and Dihedral Angles (deg)

\begin{tabular}{|c|c|c|c|c|c|}
\hline $\begin{array}{l}\text { atoms and } \\
\text { planes }\end{array}$ & $\mathrm{Os}^{8}$ & $O s^{11}$ & $\mathbf{I r}^{5}$ & $\mathrm{Ir}^{6}$ & $\mathbf{I r}^{7}$ \\
\hline \multicolumn{6}{|c|}{ Bond lengths } \\
\hline M1-Cl1 & $2.40(1)$ & $2.401(2)$ & $2.40(1)$ & $2.40(1)$ & $2.39(1)$ \\
\hline $\mathrm{M} 1-\mathrm{C} 1$ & $2.02(1)$ & $2.040(6)$ & $2.03(1)$ & $2.01(1)$ & $2.01(1)$ \\
\hline M1-N4 & $2.15(1)$ & $2.124(4)$ & $2.13(1)$ & $2.12(1)$ & $2.14(1)$ \\
\hline $\mathrm{C} 1-\mathrm{C} 2$ & $1.38(2)$ & $1.398(7)$ & $1.39(1)$ & $1.38(1)$ & $1.34(1)$ \\
\hline $\mathrm{C} 2-\mathrm{C} 3$ & $1.45(2)$ & $1.430(8)$ & $1.44(1)$ & $1.44(1)$ & $1.47(1)$ \\
\hline $\mathrm{C} 2-\mathrm{N} 1$ & $1.36(2)$ & $1.358(7)$ & $1.35(1)$ & $1.35(1)$ & $1.36(1)$ \\
\hline $\mathrm{N} 1-\mathrm{N} 2$ & $1.32(2)$ & $1.323(6)$ & $1.32(1)$ & $1.31(1)$ & $1.30(1)$ \\
\hline $\mathrm{N} 2-\mathrm{N} 3$ & $1.33(1)$ & $1.343(6)$ & $1.36(1)$ & $1.35(1)$ & $1.34(1)$ \\
\hline N3-C1 & $1.35(1)$ & $1.353(7)$ & $1.36(1)$ & $1.36(1)$ & $1.38(1)$ \\
\hline $\mathrm{N} 1-\mathrm{C} 16$ & $1.45(2)$ & $1.462(7)$ & $1.47(1)$ & $1.47(1)$ & $1.47(1)$ \\
\hline $\mathrm{N} 3-\mathrm{C} 8$ & $1.46(1)$ & $1.465(7)$ & $1.44(1)$ & $1.44(1)$ & $1.44(1)$ \\
\hline $\mathrm{C} 3-\mathrm{N} 4$ & $1.38(2)$ & $1.385(7)$ & $1.38(1)$ & $1.37(1)$ & $1.36(1)$ \\
\hline $\begin{array}{l}\text { M1- } \\
\text { center }\end{array}$ & $1.70(1)$ & $1.699(1)$ & $1.82(1)$ & $1.82(1)$ & $1.83(1)$ \\
\hline \multicolumn{6}{|l|}{ Bond angles } \\
\hline $\begin{array}{c}\mathrm{C} 1-\mathrm{M} 1- \\
\mathrm{N} 4\end{array}$ & $75.9(4)$ & $76.4(2)$ & $76.7(3)$ & $76.3(2)$ & $75.9(4)$ \\
\hline $\begin{array}{c}\mathrm{C} 1-\mathrm{M} 1- \\
\mathrm{Cl1}\end{array}$ & $85.9(3)$ & $85.4(2)$ & $88.2(2)$ & $89.7(2)$ & $87.9(3)$ \\
\hline $\begin{array}{l}\text { N4-M1- } \\
\text { Cl1 }\end{array}$ & $84.8(3)$ & $84.6(1)$ & $85.6(2)$ & $87.4(2)$ & $86.8(2)$ \\
\hline $\begin{array}{l}\mathrm{N} 3-\mathrm{C} 1- \\
\mathrm{C} 2\end{array}$ & $102.9(1)$ & $105.5(5)$ & $102.3(6)$ & $102.9(5)$ & $102.0(8)$ \\
\hline \multicolumn{6}{|c|}{ Dihedral angles } \\
\hline $\mathrm{Tz}-\mathrm{Py}$ & $5.9(4)$ & $2.0(1)$ & $7.4(2)$ & $8.5(3)$ & $10.2(3)$ \\
\hline $\mathrm{Tz}-\mathrm{Ar}$ & $48.1(5)$ & - & $44.1(2)$ & $53.0(3)$ & $56.4(3)$ \\
\hline
\end{tabular}

most toxic followed by $\mathbf{I r}^{5}$ ( $\mathrm{IC}_{50}$ of $\left.7.33 \mu \mathrm{M}\right)$. Both compounds are $\mathrm{Cp}^{*}$-iridium complexes of very similar structure having 
Table 2. Effect of the Compounds on Viability of HeLa Cells $^{a}$

\begin{tabular}{|c|c|}
\hline compound & $\mathrm{IC}_{50}(\mu \mathrm{M})$ \\
\hline$O s^{1}$ & nd \\
\hline $\mathrm{Os}^{2}$ & $33.01 \pm 6.34$ \\
\hline $\mathrm{Os}^{3}$ & nd \\
\hline $\mathrm{Os}^{4}$ & nd \\
\hline $\mathrm{Os}^{5}$ & nd \\
\hline $\mathrm{Os}^{6}$ & $24.42 \pm 5.56$ \\
\hline $\mathrm{Os}^{7}$ & nd \\
\hline $\mathrm{Os}^{8}$ & nd \\
\hline $\mathrm{Os}^{9}$ & $89.41 \pm 13.80$ \\
\hline $\mathrm{Os}^{10}$ & $100.88 \pm 11.6$ \\
\hline $\mathrm{Os}^{11}$ & nd \\
\hline $\mathrm{Os}^{12}$ & $52.81 \pm 5.97$ \\
\hline $\operatorname{Ir}^{1}$ & nd \\
\hline $\operatorname{Ir}^{2}$ & nd \\
\hline $\mathbf{I r}^{3}$ & nd \\
\hline $\mathrm{Ir}^{4}$ & $28.52 \pm 8.56$ \\
\hline $\mathbf{I r}^{5}$ & $7.33 \pm 0.28$ \\
\hline $\operatorname{Ir}^{6}$ & $17.52 \pm 0.64$ \\
\hline $\mathbf{I r}^{7}$ & $45.02 \pm 3.07$ \\
\hline $\mathbf{I r}^{8}$ & nd \\
\hline $\mathbf{I r}^{9}$ & $2.01 \pm 0.28$ \\
\hline $\mathbf{R} \mathbf{u}^{1}$ & nd \\
\hline
\end{tabular}

${ }^{a}$ nd $=$ not determined due to insufficient solubility.

the $\mathrm{N}$-wingtip ligand series, while only differing in the phenyl moiety being unsubstituted in $\mathbf{I r}^{5}$ and 2,6-diisopropyl substituted in $\mathbf{I r}$.

On the basis of the results from Table 2, compounds $\mathbf{I r}^{\mathbf{5}}$ and I $\mathbf{r}^{9}$ were selected for screening on tumor cells of different origins and one normal cell line. These included HeLa cells, laryngeal carcinoma (HEp2) cells, large cell lung carcinoma (H460) cells, colorectal carcinoma (HCT-116) cells, ovarian cancer (MES-OV) cells, and normal primary keratinocytes. The results collected in Table 3 demonstrate similar toxicity of

Table 3. Effect of $\operatorname{Ir}^{5}$ and $\operatorname{Ir}^{9}$ on Viability of Different Cell Lines

\begin{tabular}{|c|c|c|}
\hline cell line ${ }^{a}$ & $\operatorname{Ir}^{5}\left(\mathrm{IC}_{50}(\mu \mathrm{M})\right)^{b}$ & $\operatorname{Ir}^{9}\left(\operatorname{IC}_{50}(\mu \mathrm{M})\right)^{b}$ \\
\hline HeLa & $7.33 \pm 0.28$ & $2.01 \pm 0.28$ \\
\hline HEp2 & $13.30 \pm 1.20$ & $4.66 \pm 0.59$ \\
\hline $\mathrm{H} 460$ & $6.00 \pm 0.90$ & $3.2 \pm 0.89$ \\
\hline HCT-116 & $6.50 \pm 0.81$ & $3.02 \pm 0.17$ \\
\hline MES-OV & $7.6 \pm 0.86$ & $4.08 \pm 0.5$ \\
\hline keratinocytes & $<100$ & $<100$ \\
\hline
\end{tabular}

${ }^{a} \mathrm{HeLa}=$ cervical carcinoma cells; HEp2 = laryngeal carcinoma cells; $\mathrm{H} 460$ = large cell lung carcinoma cells; HCT-116 = colorectal carcinoma cells; MES-OV = ovarian cancer cells; Keratinocytes = normal primary keratinocytes. ${ }^{b}$ The data are shown as mean values of three experiments $( \pm S D)$.

both compounds on all tested tumor cell lines independent from their origin, with $\mathbf{I r}^{9}$ being consistently more cytotoxic than $\mathbf{I r}^{5}$. One of the most important features of a compound to be considered as potential anticancer agent is selectivity, i.e., as high as possible cytotoxicity against tumor as compared to the nontumor cells. It is noteworthy that all examined tumor cell lines proved to be considerably more sensitive to both compounds as compared to the normal cell line, normal primary keratinocytes (Table 3). The therapeutic index was not calculated since the $\mathrm{IC}_{50}$ doses of both compounds in keratinocytes could not be determined.

Cell Cycle and Cell Death Analysis. To shed light into the mode of action that underlies the antiproliferative or/and toxic activity of $\mathbf{I r}^{\mathbf{5}}$ and $\mathbf{I} \mathbf{r}^{9}$, we first investigated their effect on the cell cycle. The flow cytometric analysis upon propidium iodide staining of cells treated with different concentrations of $\mathbf{I r}^{5}$ and $\mathbf{I r}^{9}$ during $72 \mathrm{~h}$ (Figure $2 \mathrm{~A}$ ) or with $7 \mu \mathrm{M} \mathrm{Ir} \mathbf{I r}^{5}$ and $2 \mu \mathrm{M}$ $\mathrm{Ir}^{9}$ during 24-72 $\mathrm{h}$ (Figure 2B) was performed. It seems that both compounds tend to arrest cells in the G2 phase of the cell cycle, and push the cells further into cell death. But, it is interesting to notice that $\mathrm{IC}_{50}$ dose of $\mathbf{I r}^{5}$ induces accumulation of cells in the $S$ phase of cell cycle, which is not a case for $\mathrm{IC}_{50}$ of Ir $^{9}$. The $S$ phase arrest implies problems with DNA replication that triggers a "checkpoint" - a cascade of signaling events that puts the phase on hold until the problem is resolved. It seems that these cells are unable to progress through $S$ phase when the checkpoint is inhibited and often enter directly into premature mitosis. ${ }^{13}$ Further investigation is needed to understand why this effect is seen only upon $\mathbf{I r}^{5}$ treatment and not after the treatment with $\mathbf{I r}^{9}$. The SubG0/G1 cell population, which is measured in cell cycles analysis as well, is characterized with a lower amount of DNA. The cells that entered apoptosis from the G2/M phase of the cell cycle or have lost DNA for any other reason, e.g., death by some other form of oncosis, will appear in the SubG0/G1 region. The $\mathbf{I r}^{5}$ and $\mathbf{I r}^{9}$ induce dose- and time-dependent increase of SubG0/G1 cell population (Figure $2 \mathrm{~A}$ and $2 \mathrm{~B}$ ).

To shed more light on the type of cell death, HeLa cells were treated with $\mathbf{I r}^{5}(7 \mu \mathrm{M})$ or $\mathbf{I r}^{9}(2 \mu \mathrm{M})$, following the Annexin V-FITC and PI staining 24-72 $\mathrm{h}$ after. The analyzed data shown in Figure 3A indicated that the majority of cells die by apoptosis, which we further confirmed by detection of cleaved PARP, a well-accepted apoptotic marker, ${ }^{14}$ in the treated cells. As shown in Figure 3B, the treatment of HeLa cells with $7 \mu \mathrm{M}$ of $\mathbf{I r}^{9}$ induced cleavage of PARP already $24 \mathrm{~h}$ after the treatment. Due to the lower toxicity, the cleaved PARP was not detected upon cell treatment with the same concentration of $\operatorname{Ir}^{5}(7 \mu \mathrm{M})$. However, when the equitoxic doses of $\mathbf{I r}^{5}(33 \mu \mathrm{M})$ and $\mathbf{I r}^{9}(10 \mu \mathrm{M})$ were used the cleavage of PARP was detected for both compounds after $72 \mathrm{~h}$ treatment (Figure $3 \mathrm{C}$ ). In addition, $72 \mathrm{~h}$ upon cell treatment with $7 \mu \mathrm{M}$ and $33 \mu \mathrm{M}$ of $\mathbf{I r}^{5}$, and $2 \mu \mathrm{M}$ and $10 \mu \mathrm{M}$ of $\mathbf{I r}^{9}$, the activity of executor caspases 3 and 7 was measured. The results showed that both compounds activated caspases $3 / 7$, although the activation was more visible upon $\mathbf{I r}^{\mathbf{5}}$ treatment (Figure 3D). It is likely that $\mathbf{I r}^{9}$ induces the activity of other caspases such as caspase $1 .^{15}$ The possible involvement of autophagy and necroptosis as cell death models was checked by pretreatment of cells with bafilomycin A (BAF A), a known inhibitor of the late phase of autophagy, ${ }^{16}$ and with the inhibitor of necroptosis, necrostatin-1 (Nec-1). ${ }^{17}$ Afterward, the cells were treated with different concentrations of either $\mathbf{I r}^{\mathbf{5}}$ or $\mathbf{I r}^{9}$. Both inhibitors failed in protection of the cells from cell death, indicating that neither autophagy nor necroptosis are involved in cell death induced by $\mathbf{I r}^{5}$ or $\mathbf{I r}^{9}$ (Figure 3E).

One of the possibilities for higher toxicity of $\operatorname{Ir}^{9}$ compared to $\mathbf{I r}^{5}$ could be increased accumulation of $\mathbf{I r}^{9}$ in the cells due to the small structural difference. In order to test this hypothesis, we treated HeLa cells with different concentrations of both compounds during $3 \mathrm{~h}$ and measured the accumulation of iridium by high resolution inductively coupled plasma mass 

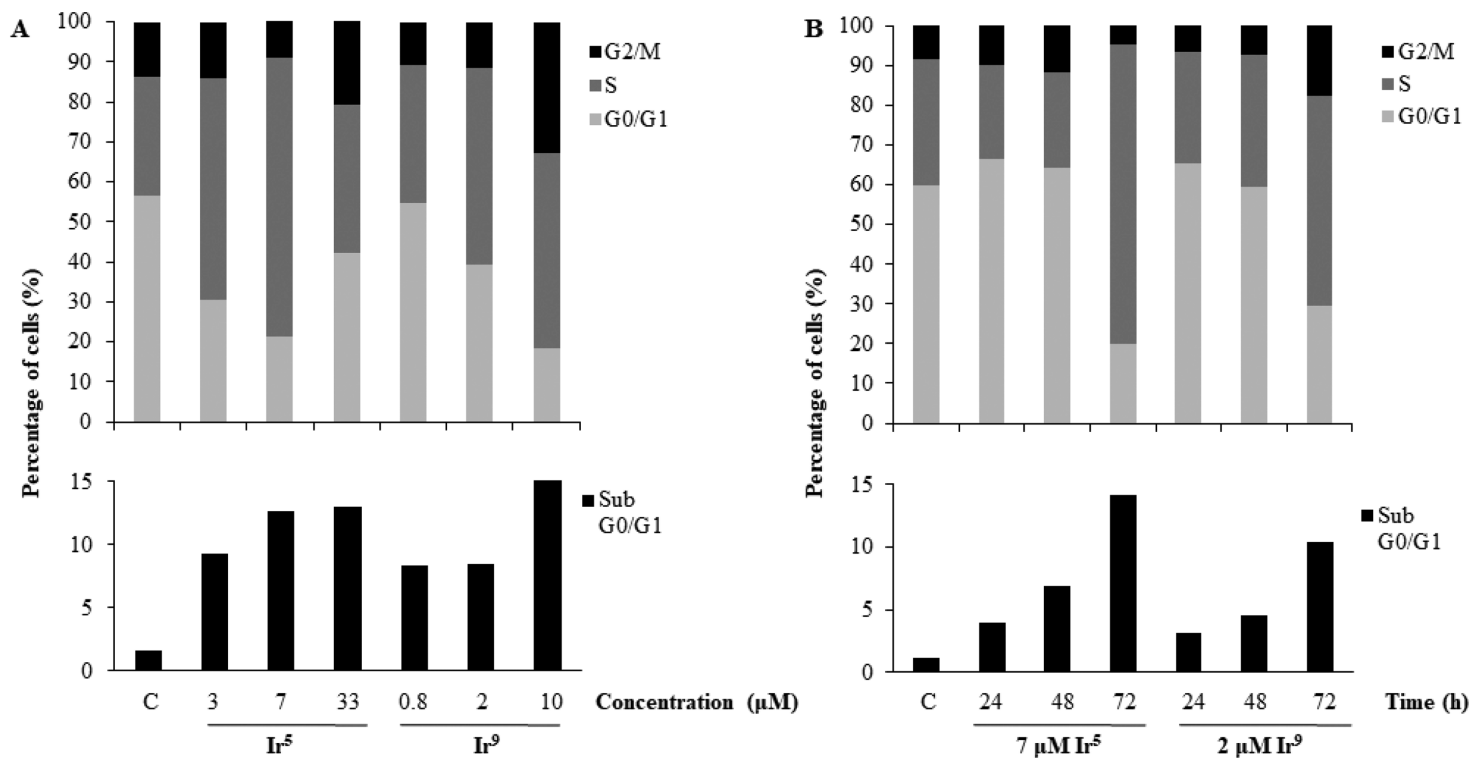

Figure 2. Effects of $\mathbf{I r}^{5}$ and $\mathbf{I r}^{9}$ on cell cycle. HeLa cells were treated either with different concentrations of $\mathbf{I r}^{5}$ and $\mathbf{I r}^{9}$ during $72 \mathrm{~h}$ (A) or with equitoxic doses of $\mathbf{I r}^{5}(7 \mu \mathrm{M})$ and $\operatorname{Ir}^{9}(2 \mu \mathrm{M})$ during $24-72 \mathrm{~h}(\mathrm{~B})$. A cell cycle distribution was assessed as described in the Experimental Section. Data of one from three independent experiments are presented.

spectrometry (HR ICPMS). The accumulation of both compounds in the cells increased with the time, but the content of iridium upon $\mathbf{I r}^{9}$ was higher than the one measured upon $\mathbf{I r}^{5}$ treatment (Figure 4). The higher level of $\mathbf{I r}^{9}$ in the cell, compared to the level of $\mathbf{I r}^{5}$, could be one of the reasons for its greater toxicity.

The Role of Glutathione (GSH) in Cell Response to Ir $^{5}$ and $1 r^{9}$. The role of GSH as a cell defense mechanism is well described in the literature. ${ }^{18,19}$ Previously, we described GSH as an important factor in the protection of cell upon induction of reactive oxygen species (ROS), ${ }^{20,21}$ and upon treatment with newly synthesized ${ }^{12}$ or newly isolated compounds. ${ }^{22}$ Recently, we identified a triazolium salt of 4-(4-methoxyphenyl)-3-methyl-1-(2-picolyl)-1H-1,2,3-triazolium hexafluorophosphate(V) structure, which induced ROS and showed that GSH is involved in reduction of ROS-induced toxicity. ${ }^{7}$ Here we show that pretreatment of HeLa cells with buthionine sulfoximine (BSO), a specific inhibitor of GSH synthesis, decreased cell survival upon treatment with $\mathbf{I r}^{5}$ and Ir' $^{9}$ (Figure 5A). The data imply a role of GSH in cell defense against damages induced by both investigated compounds. The important role of GSH in cell-stress protection was further confirmed by pretreatment of cells with $\mathrm{N}$-acetyl-cysteine (NAC), a precursor of GSH synthesis. Increased GSH amount in the cell protects it against either $\mathbf{I r}^{5}$ or $\mathbf{I} \mathbf{r}^{9}$ toxicity (Figure $5 B)$. The protection role of GSH is more expressed in HeLa cells upon $\mathbf{I r}^{9}$ treatment as compared to $\mathbf{I r}^{5}$. In order to investigate the possibility of ROS-induced toxicity by $\mathbf{I r}^{5}$ and $\mathbf{I r}^{9}$, we stained cells upon treatment with fluorescent dye 5(and-6)-chloromethyl-29,79-dichlorodihydrofluorescein diacetate, acetyl ester (CM- $\mathrm{H}_{2}$ DCFDA). The data obtained indicate that neither $\mathbf{I r}^{5}$ nor $\mathbf{I r}^{9}$ induce ROS (Figure 5C). This was further confirmed by pretreatment of cells with a well-accepted ROS scavenger tempol, which did not change survival rate of cells compared to the one treated only with compounds $\mathbf{I r}^{5}$ and $\mathbf{I r}^{9}$ (Figure 5D). It is known that GSH has a role in other physiological processes such as nutrient metabolism, defense by detoxification, and regulation of cellular metabolic functions ranging from gene expression, DNA, and protein synthesis to signal transduction, cell proliferation, and apoptosis. ${ }^{23}$ Previously, we showed importance of GSH detoxification role in cell defense against toxicity of several compounds. ${ }^{24}$ Elucidating the mechanisms through which GSH is involved in defense against chlorido arene-iridium(III) complexes with bidentate pyridyl functionalized mesoionic carbenes (MIC) of the 1,2,3-triazol-5-ylidene type will be interesting for future investigation.

\section{CONCLUSION}

We have synthesized 12 osmium(II), 9 iridium(III), and 1 ruthenium(II) chloride arene organometallic compounds that are additionally coordinated with bidentate pyridyl and pyrimidyl functionalized mesoionic carbenes (MIC) of the 1,2,3-triazol-5-ylidene type. All new compounds have been fully characterized by means of standard analytical and spectroscopic techniques. For five of them we were able to provide X-ray structural analysis. The complexes have been tested for their anticancer activity, and it is noteworthy that this is the first report on biological activity of this type of organometallic compounds. $\mathbf{I r}^{\mathbf{5}}$ and $\mathbf{I r}^{\mathbf{9}}$ displayed the highest effect on cell viability in HeLa cells. They had a similar effect on different tumor cell lines, but they were more cytotoxic against tumor cells than normal cells. Moreover, both complexes induced programmed cell death. GSH plays an important role as a protection mechanism in $\mathbf{I r}^{\mathbf{5}}$ - and $\mathbf{I r}^{\mathbf{9}}$ induced cell death. Organoiridium complexes seem very interesting for further investigation as potential anticancer agents due to their selective highly toxic effect on different tumor cell types.

\section{EXPERIMENTAL SECTION}

Chemistry. The reagents and solvents were used as obtained from the commercial sources (Sigma-Aldrich, Fluka, Alfa Aesar). $\mathrm{Ag}_{2} \mathrm{O}^{25}$ triazolium salts $\mathbf{L}^{1}-\mathbf{L}^{13},{ }^{10}$ complexes $\mathbf{O s}^{1}-\mathbf{O s}^{7},{ }^{8 \mathrm{~b}} \mathbf{O s}^{12},{ }^{8 \mathrm{~d}} \mathbf{I r}^{1}-\mathbf{I r}^{\mathbf{4}}$, $\mathbf{I r}^{\mathbf{8}}{ }^{8 \mathrm{c}}$ and $\mathbf{R} \mathbf{u}^{18 \mathrm{~d}}$ were prepared as described previously.

NMR spectra were measured with a Jeol ECS 400 spectrometer at $25{ }^{\circ} \mathrm{C}$. Proton and carbon spectra were referenced to $\mathrm{Si}\left(\mathrm{CH}_{3}\right)_{4}$ as the internal standard. Chemical shifts are given on the $\delta$ scale (ppm). 

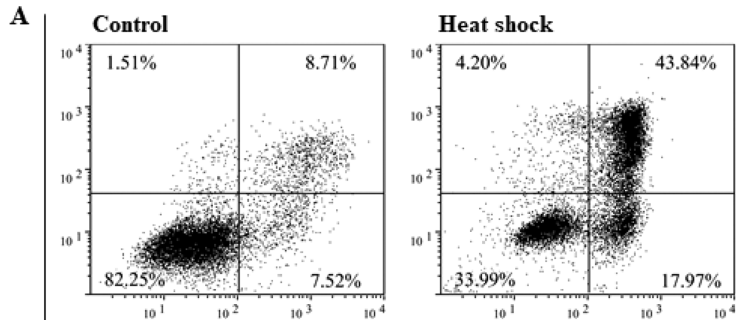

Ir $^{5} 7 \mu \mathrm{M}$

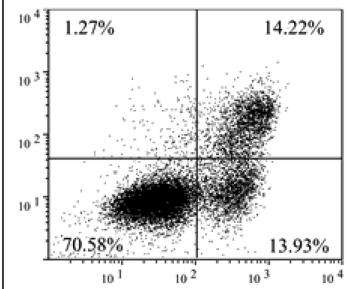

穴
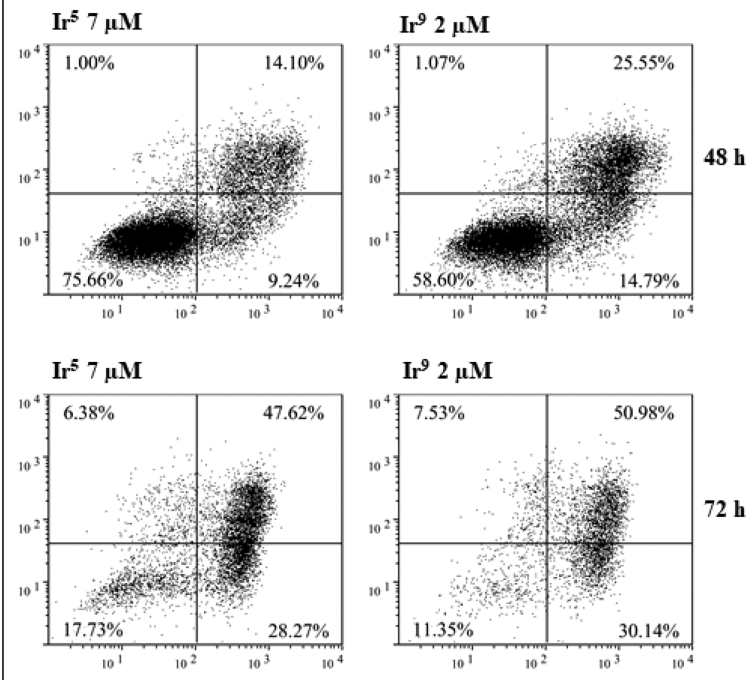

Annexin V-FITC

E

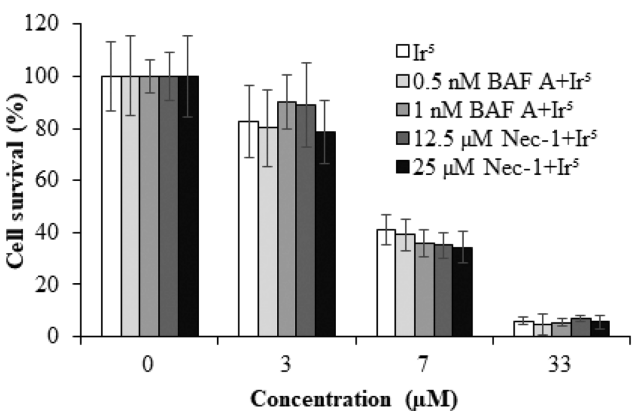

B

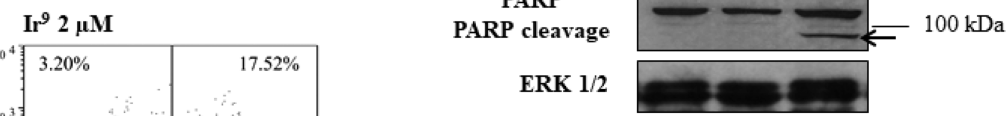

24 h

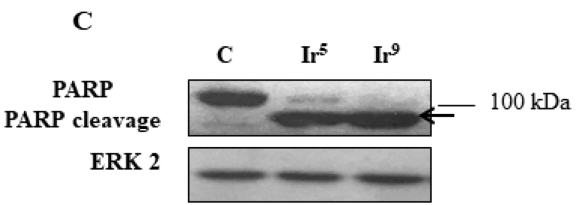

8 h
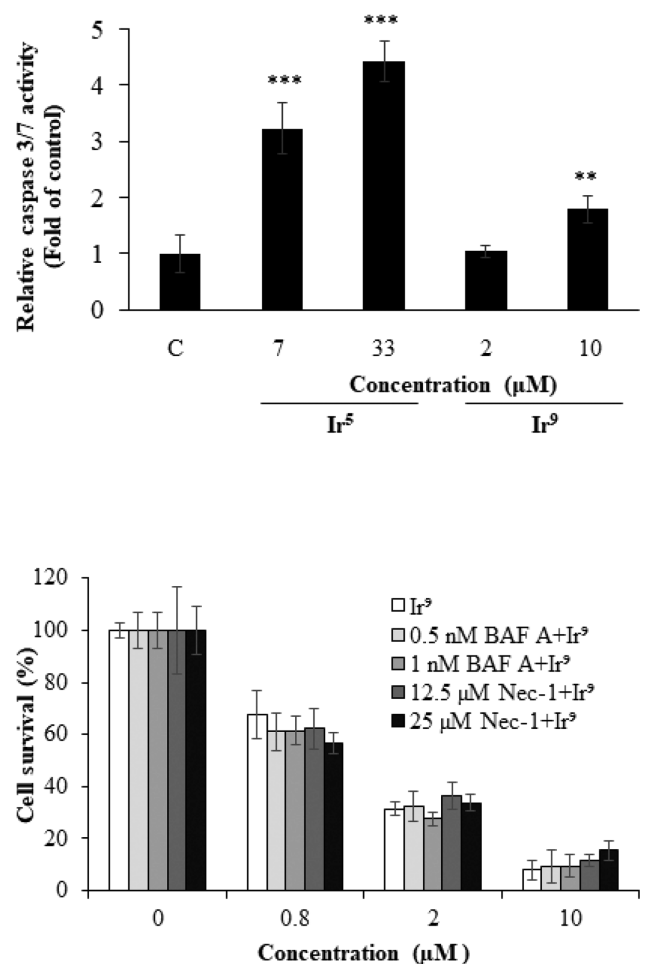

Figure 3. Impact of $\mathbf{I r}^{5}$ and $\mathbf{I r}^{9}$ on cell death. HeLa cells were treated with $7 \mu \mathrm{M} \mathbf{I r}^{5}$ and $2 \mu \mathrm{M} \mathbf{I r}^{9}$ during $24-72$ h. The percent of live, early apoptotic, and late apoptotic/necrotic cells are shown. The data of one from three independent experiments are presented. Heat shock was used to adjust data analysis parameters $\left(10 \mathrm{~min}, 56^{\circ} \mathrm{C}\right)(\mathrm{A})$. HeLa cells were treated $24 \mathrm{~h}$ with equimolar concentration $(7 \mu \mathrm{M})$ of $\mathbf{I r}^{5}$ and $\mathbf{I r}^{9}(\mathrm{~B})$ and with equitoxic concentrations, $\mathbf{I r}^{5}(33 \mu \mathrm{M})$ and $\operatorname{Ir}^{9}(10 \mu \mathrm{M})$ during $72 \mathrm{~h}(\mathrm{C})$. Control cells were collected either at $24(\mathrm{~B})$ or $72 \mathrm{~h}(\mathrm{C})$ time points. Precision Plus Protein All Blue Prestained Protein Standard (Bio-Rad, USA) is indicated in the figure. ERK1/2 (B) and ERK2 (C) were used as loading controls. Data of one from three independent experiments are presented. HeLa cells were treated with $\operatorname{Ir}^{5}(7 \mu \mathrm{M}$ and $33 \mu \mathrm{M})$ and $\mathbf{I r}^{9}(2$ $\mu \mathrm{M}$ and $10 \mu \mathrm{M})$. The activity of caspase $3 / 7$ was measured after $72 \mathrm{~h}$. The values are presented as fold of control. Significance was determined between control (nontreated) and $\mathbf{I r}^{5}$, respectively, $\mathbf{I r}^{9}$ treated cells $(* P<0.05 ; * * P<0.01 ; * * * P<0.001)$. The experiment was repeated at least three times (D). HeLa cells were pretreated either with 0.5 and $1 \mathrm{nM}$ BAF A or 12.5 and $25 \mu \mathrm{M} \mathrm{Nec}-1$. Two hours later the cells were treated with different concentrations of $\mathbf{I r}^{5}$ and $\mathbf{I r}^{9}$. Cell survival was determined $72 \mathrm{~h}$ later by MTT assay. Each point represents mean \pm SD of at least three independent experiments. All data are expressed as the average percentage of survival values relative to the untreated control \pm SD or samples treated with inhibitors alone $(\mathrm{E})$. 


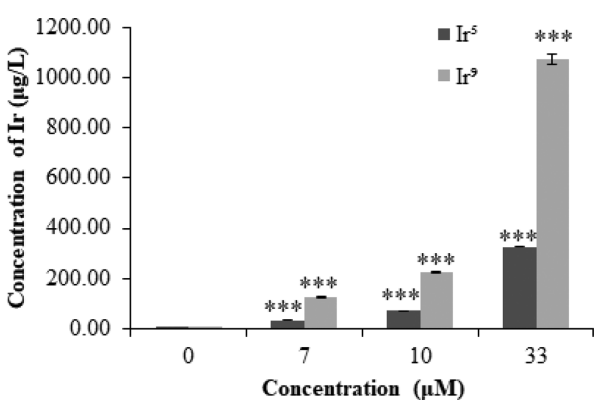

Figure 4. The accumulation of $\mathbf{I r}^{5}$ and $\mathbf{I r}^{9}$ in cells. HeLa cells were treated with different concentrations of $\mathbf{I r}^{5}$ or $\mathbf{I r}^{9}$ for $3 \mathrm{~h}$. The cells were collected, and the amount of iridium was measured by HR ICPMS. The data of three independent experiments are presented. Significance was determined between control (nontreated) and $\mathbf{I r}^{5}$, respectively, $\mathbf{I r}^{9}$ treated cells $(* * * P<0.001)$.

Coupling constants $(J)$ are given in Hertz. The multiplicities are indicated as follows: $\mathrm{s}$ (singlet), $\mathrm{d}$ (doublet), $\mathrm{t}$ (triplet), $\mathrm{q}$ (quartet), sept (septet), and $\mathrm{m}$ (multiplet). An Agilent 6210 ESI-TOF spectrometer and Agilent 6224 time-of-flight (TOF) mass spectrometer equipped with a double orthogonal electrospray source at atmospheric pressure ionization (ESI) coupled to an Agilent 1260 HLPC were used for recording HRMS spectra.

X-ray data were collected with a Bruker Smart AXS. Data were collected at $140(2) \mathrm{K}$ using graphite-monochromated Mo K $\alpha$ radiation $(\mathrm{K} \alpha=0.71073 \AA)$. The strategy for the data collection was evaluated using the Smart software. The data were collected by the standard "omega scan techniques" and were scaled and reduced using Saint+ software. The structures were solved by direct methods using SHELXS-97 and refined by full matrix least-squares with SHELXL-97, refining on $\mathrm{F}^{2}{ }^{26}$

General Procedure for the Preparation of Complexes $\mathrm{Os}^{8}$ $0 s^{11}$ and $\left|r^{5}-\right| r^{7}, I r^{9}$. The corresponding ligand precursor (2 equiv, $0.2 \mathrm{mmol}$ ) was mixed with basic silver(I) oxide (7 equiv, $0.7 \mathrm{mmol}$, $163 \mathrm{mg}$ ) and potassium chloride (20 equiv, $2 \mathrm{mmol}, 155 \mathrm{mg}$ ) and was dissolved under nitrogen in dry acetonitrile $(10 \mathrm{~mL})$. The reaction mixture was stirred under the exclusion of light for 2 days. Afterward, the corresponding chloro-bridged metal dimer precursor ( 1 equiv, 0.1 $\mathrm{mmol}$ ) was added and stirring was continued for additional 2-3 days. The remaining silver(I) oxide and silver(I) chloride that formed were filtered off through a pad of Celite, and all volatiles were removed in vacuo. The crude product was then dissolved in methanol $(5 \mathrm{~mL})$. $\mathrm{KPF}_{6}$ (8 equiv, $0.8 \mathrm{mmol}, 147 \mathrm{mg}$ ) was added, and the solution was stirred for $20 \mathrm{~min}$. Slow addition of water $(80 \mathrm{~mL})$ resulted in precipitation of the desired complexes, which were collected by filtration and air-dried. If the precipitation from water was not successful, the product was extracted with dichloromethane $(3 \times 20$ $\mathrm{mL})$. Combined organic layers were dried over $\mathrm{NaSO}_{4}$ and concentrated to ca. $5 \mathrm{~mL}$ volume. The product was precipitated by the addition of hexane $(50 \mathrm{~mL})$ and collected by filtration. The complexes were obtained in moderate yields of $53 \%$ and higher.

Osmium Complexes. Os $^{8}$. From $\mathbf{L}^{8}(65 \mathrm{mg})$ and $[\mathrm{Os}(p-$ Cym $\left.)_{2}\right]_{2}(79 \mathrm{mg})$. Green solid. Yield: $65 \%(0.13 \mathrm{mmol}, 96.4$ $\mathrm{mg}){ }^{1} \mathrm{H}$ NMR $\left(400 \mathrm{MHz}, \mathrm{CD}_{2} \mathrm{Cl}_{2}\right) \delta=9.18(\mathrm{td}, J=5.7,0.7 \mathrm{~Hz}, 1 \mathrm{H}$, Py $-H$ ), $8.01(\mathrm{td}, J=8.1,0.7 \mathrm{~Hz}, 1 \mathrm{H}, \mathrm{Py}-H), 7.96$ (ddd, $J=8.1,1.4$, $0.6 \mathrm{~Hz}, 1 \mathrm{H}, \mathrm{Py}-H), 7.86$ (ddd, $J=5.5,2.4,1.1 \mathrm{~Hz}, 2 \mathrm{H}, \mathrm{Ar}-H$ ), 7.67-7.61 (m, 3H, Ar-H), $7.37(\mathrm{ddd}, 1 \mathrm{H}, \mathrm{Py}-\mathrm{H}), 5.40(\mathrm{dd}, J=13.7$, $5.8 \mathrm{~Hz}, 2 \mathrm{H}, \mathrm{Cym}-\mathrm{CH}), 5.23(\mathrm{~d}, J=5.6 \mathrm{~Hz}, 1 \mathrm{H}, \mathrm{Cym}-\mathrm{CH}), 4.84(\mathrm{~d}$, $J=5.6 \mathrm{~Hz}, 1 \mathrm{H}, \mathrm{Cym}-\mathrm{CH}), 4.53\left(\mathrm{~s}, 3 \mathrm{H}, \mathrm{N}-\mathrm{CH}_{3}\right), 2.24(\mathrm{sept}, J=6.9$ $\left.\mathrm{Hz}, 1 \mathrm{H}, \mathrm{CH}\left(\mathrm{CH}_{3}\right)_{2}\right), 2.08\left(\mathrm{~s}, 3 \mathrm{H}, \mathrm{Cym}-\mathrm{CH}_{3}\right), 0.86(\mathrm{~d}, J=6.9 \mathrm{~Hz}$, $\left.3 \mathrm{H}, \mathrm{CH}\left(\mathrm{CH}_{3}\right)_{2}\right), 0.84\left(\mathrm{~d}, J=6.9 \mathrm{~Hz}, 3 \mathrm{H}, \mathrm{CH}\left(\mathrm{CH}_{3}\right)_{2}\right) .{ }^{13} \mathrm{C} \mathrm{NMR}$ $\left(100 \mathrm{MHz}, \mathrm{CD}_{2} \mathrm{Cl}_{2}\right) \delta=160.9(\mathrm{Tz}-\mathrm{C}), 157.8 ; 148.6 ; 147.5,139.7$, 137.8, 131.4, 130.0, 126.3, 125.4, 121.2 (all Ar/Py-C), 99.1, 98.4, 81.9, 77.7, 77.6, 72.4 (all Cym-C), $39.2\left(\mathrm{~N}-\mathrm{CH}_{3}\right), 31.4(\mathrm{CH}-$ $\left.\left(\mathrm{CH}_{3}\right)_{2}\right), 22.6\left(\mathrm{CH}\left(\mathrm{CH}_{3}\right)_{2}\right), 21.7\left(\mathrm{CH}\left(\mathrm{CH}_{3}\right)_{2}\right), 18.6\left(\mathrm{Cym}-\mathrm{CH}_{3}\right)$. HRMS (ESI+) $m / z$ calcd. for $\mathrm{C}_{24} \mathrm{H}_{26} \mathrm{ClN}_{4} \mathrm{Os}^{+}[\mathrm{M}]^{+}=597.1461$, found 597.1464 .
Os ${ }^{9}$. From $\mathrm{L}^{9}(71 \mathrm{mg})$ and $\left[\mathrm{Os}(p-\mathrm{Cym}) \mathrm{Cl}_{2}\right]_{2}(79 \mathrm{mg})$. Gray-green solid. Yield: 53\% (0.106 mmol, $82 \mathrm{mg}) .{ }^{1} \mathrm{H}$ NMR (400 $\mathrm{MHz}$, $\left.\mathrm{CD}_{2} \mathrm{Cl}_{2}\right) \delta=9.17(\mathrm{dt}, J=5.7,1.1 \mathrm{~Hz}, 1 \mathrm{H}, \mathrm{Py}-\mathrm{H}), 8.03-7.98(\mathrm{~m}, 1 \mathrm{H}$, $\mathrm{Py}-H), 7.94(\mathrm{dt}, J=8.1,1.1 \mathrm{~Hz}, 1 \mathrm{H}, \mathrm{Py}-H), 7.77(\mathrm{~d}, J=9.0 \mathrm{~Hz}, 2 \mathrm{H}$, $\mathrm{Ar}-H$ ), 7.36 (ddd, $J=7.4,5.7,1.5 \mathrm{~Hz}, 1 \mathrm{H}, \mathrm{Py}-H), 7.09$ (d, $J=9.0$ $\mathrm{Hz}, 2 \mathrm{H}, \mathrm{Ar}-\mathrm{H}), 5.44(\mathrm{dd}, J=5.8,1.1 \mathrm{~Hz}, 1 \mathrm{H}, \mathrm{Cym}-\mathrm{CH}), 5.38(\mathrm{~d}, J$ $=5.9 \mathrm{~Hz}, 1 \mathrm{H}, \mathrm{Cym}-\mathrm{CH}), 5.28(\mathrm{~d}, J=5.9 \mathrm{~Hz}, 1 \mathrm{H}, \mathrm{Cym}-\mathrm{CH}), 4.86$ $(\mathrm{dd}, J=5.5,1.1 \mathrm{~Hz}, 1 \mathrm{H}, \mathrm{Cym}-\mathrm{CH}), 4.51\left(\mathrm{~s}, 3 \mathrm{H}, \mathrm{N}-\mathrm{CH}_{3}\right), 3.87(\mathrm{~s}$, $\left.3 \mathrm{H}, \mathrm{O}-\mathrm{CH}_{3}\right), 2.24$ (sept, $\left.J=7.0 \mathrm{~Hz}, 1 \mathrm{H}, \mathrm{CH}\left(\mathrm{CH}_{3}\right)_{2}\right), 2.09(\mathrm{~s}, 3 \mathrm{H}$, $\left.\mathrm{Cym}-\mathrm{CH}_{3}\right), 0.86\left(\mathrm{~d}, J=6.9 \mathrm{~Hz}, 3 \mathrm{H}, \mathrm{CH}\left(\mathrm{CH}_{3}\right)_{2}\right), 0.85(\mathrm{~d}, J=6.9 \mathrm{~Hz}$, $3 \mathrm{H}, 21.7\left(\mathrm{CH}\left(\mathrm{CH}_{3}\right)_{2}\right) .{ }^{13} \mathrm{C}$ NMR $\left(100 \mathrm{MHz}, \mathrm{CD}_{2} \mathrm{Cl}_{2}\right) \delta=160.9(\mathrm{Ar}-$ C), $160.8(\mathrm{Tz}-\mathrm{C}), 160.0,157.0,147.9,147.5,138.9,129.7,125.9$, 125.4, 120.4, 114.9 (all Ar/Py-C), 98.2, 97.9, 81.0, 76.9, 76.8, 71.2 (all $\mathrm{Cym}-\mathrm{C}), 55.1\left(\mathrm{O}-\mathrm{CH}_{3}\right), 38.3\left(\mathrm{~N}-\mathrm{CH}_{3}\right), 30.6\left(\mathrm{CH}\left(\mathrm{CH}_{3}\right)_{2}\right)$, $21.8\left(\mathrm{CH}\left(\mathrm{CH}_{3}\right)_{2}\right), 21.0\left(\mathrm{CH}\left(\mathrm{CH}_{3}\right)_{2}\right), 17.8,13.06\left(\mathrm{Cym}-\mathrm{CH}_{3}\right)$. HRMS (ESI+) $m / z$ calcd. for $\mathrm{C}_{25} \mathrm{H}_{28} \mathrm{ClN}_{4} \mathrm{OOs}^{+}[\mathrm{M}]^{+}=627.1566$, found 627.1576 .

$\mathrm{Os}^{10}$. From L $\mathbf{L}^{10}(78 \mathrm{mg})$ and $\left[\mathrm{Os}(p-\mathrm{Cym}) \mathrm{Cl}_{2}\right]_{2}(79 \mathrm{mg})$. Yellow solid. Yield: $61 \%(0.122 \mathrm{mmol}, 98 \mathrm{mg}) .{ }^{1} \mathrm{H}$ NMR $(400 \mathrm{MHz}$ $\left.\mathrm{CD}_{2} \mathrm{Cl}_{2}\right) \delta=9.17(\mathrm{~d}, J=5.8,1.0 \mathrm{~Hz}, 1 \mathrm{H}, \mathrm{Py}-H), 8.11(\mathrm{~d}, J=8.8 \mathrm{~Hz}$, $2 \mathrm{H}, \mathrm{Ar}-\mathrm{H}), 8.03(\mathrm{dd}, J=7.9,1.3 \mathrm{~Hz}, 1 \mathrm{H}, \mathrm{Py}-H), 7.96(\mathrm{~d}, J=8.1 \mathrm{~Hz}$, $1 \mathrm{H}, \mathrm{Py}-H), 7.91(\mathrm{~d}, J=8.9 \mathrm{~Hz}, 2 \mathrm{H}, \mathrm{Ar}-\mathrm{H}), 7.38$ (ddd, $J=7.3,5.9$, $1.4 \mathrm{~Hz}, 1 \mathrm{H}, \mathrm{Py}-H), 5.43(\mathrm{~d}, J=5.9 \mathrm{~Hz}, 1 \mathrm{H}, \mathrm{Cym}-\mathrm{CH}), 5.39(\mathrm{~d}, J=$ $5.8 \mathrm{~Hz}, 1 \mathrm{H}, \mathrm{Cym}-\mathrm{CH}), 5.32(\mathrm{~d}, J=5.9 \mathrm{~Hz}, 1 \mathrm{H}, \mathrm{Cym}-\mathrm{CH}), 4.89(\mathrm{~d}$, $J=5.6 \mathrm{~Hz}, 1 \mathrm{H}, \mathrm{Cym}-\mathrm{CH}), 4.55\left(\mathrm{~s}, 3 \mathrm{H}, \mathrm{N}-\mathrm{CH}_{3}\right), 2.27$ (sept, $J=6.9$ $\left.\mathrm{Hz}, 1 \mathrm{H}, \mathrm{CH}\left(\mathrm{CH}_{3}\right)_{2}\right), 2.09\left(\mathrm{~s}, 3 \mathrm{H}, \mathrm{Cym}-\mathrm{CH}_{3}\right), 0.88(\mathrm{~d}, J=6.9 \mathrm{~Hz}$ $\left.3 \mathrm{H}, \mathrm{CH}\left(\mathrm{CH}_{3}\right)_{2}\right), 0.87\left(\mathrm{~d}, J=6.9 \mathrm{~Hz}, 3 \mathrm{H}, \mathrm{CH}\left(\mathrm{CH}_{3}\right)_{2}\right) .{ }^{13} \mathrm{C}$ NMR $\left(100 \mathrm{MHz}, \mathrm{CD}_{2} \mathrm{Cl}_{2}\right) \delta=160.2(\mathrm{Tz}-\mathrm{C}), 156.9,147.7,147.0,140.0$, 128.1, 126.5 (q, $J=4 \mathrm{~Hz}, \mathrm{Ar}-C), 125.6,125.4,125.3$, 120.6, (all Ar/ $\mathrm{Py}-\mathrm{C}), 99.0,97.5,80.8,77.1,77.0,72.0($ all $\mathrm{Cym}-\mathrm{C}), 38.6(\mathrm{~N}-$ $\left.\mathrm{CH}_{3}\right), 30.6\left(\mathrm{CH}\left(\mathrm{CH}_{3}\right)_{2}\right), 21.9\left(\mathrm{CH}\left(\mathrm{CH}_{3}\right)_{2}\right), 20.9\left(\mathrm{CH}\left(\mathrm{CH}_{3}\right)_{2}\right), 17.8$ $\left(\mathrm{Cym}-\mathrm{CH}_{3}\right)$. HRMS (ESI+) $\mathrm{m} / z$ calcd. for $\mathrm{C}_{25} \mathrm{H}_{25} \mathrm{ClF}_{3} \mathrm{~N}_{4} \mathrm{Os}^{+}[\mathrm{M}]^{+}$ $=665.1335$, found 665.1340 .

$\mathrm{Os}^{11}$. From $\mathrm{L}^{11}(55 \mathrm{mg})$ and $\left[\mathrm{Os}(\mathrm{Cym}) \mathrm{Cl}_{2}\right]_{2}(79 \mathrm{mg})$. Yellow solid. Yield: $69 \%(0.137 \mathrm{mmol}, 95 \mathrm{mg}) .{ }^{1} \mathrm{H}$ NMR $(400 \mathrm{MHz}$ $\left.\mathrm{CD}_{2} \mathrm{Cl}_{2}\right) \delta=9.23-9.17(\mathrm{~m}, 1 \mathrm{H}, \mathrm{Py}-\mathrm{H}), 8.05-7.99(\mathrm{~m}, 1 \mathrm{H}, \mathrm{Py}-\mathrm{H})$, 7.94-7.88 (m, 1H, Py-H), 7.41-7.34 (m, 1H, Py-H), $5.95(\mathrm{~d}, J=$ $5.6 \mathrm{~Hz}, 1 \mathrm{H}, \mathrm{Cym}-\mathrm{CH}), 5.85(\mathrm{~d}, J=6.1,1 \mathrm{H}, \mathrm{Cym}-\mathrm{CH}), 5.78(\mathrm{~d}, J=$ 5.8, $1 \mathrm{H}, \mathrm{Cym}-\mathrm{CH}), 5.49(\mathrm{~d}, J=5.8,1 \mathrm{H}, \mathrm{Cym}-\mathrm{CH}), 4.78-4.57(\mathrm{~m}$, $2 \mathrm{H}, \mathrm{N}-\mathrm{CH}_{2} \mathrm{CH}_{3}$ ), $4.45\left(\mathrm{~s}, 3 \mathrm{H}, \mathrm{N}-\mathrm{CH}_{3}\right), 2.36$ (sept, $J=6.9 \mathrm{~Hz}, 1 \mathrm{H}$, $\left.\mathrm{CH}\left(\mathrm{CH}_{3}\right)_{2}\right), 2.21\left(\mathrm{~s}, 3 \mathrm{H}, \mathrm{Cym}-\mathrm{CH}_{3}\right), 1.66(\mathrm{t}, J=7.4 \mathrm{~Hz}, 3 \mathrm{H}, \mathrm{N}-$ $\left.\mathrm{CH}_{2} \mathrm{CH}_{3}\right), 0.98-0.90\left(\mathrm{~m}, 6 \mathrm{H}, \mathrm{CH}\left(\mathrm{CH}_{3}\right)_{2}\right) .{ }^{13} \mathrm{C}$ NMR $(100 \mathrm{MHz}$ $\left.\mathrm{CD}_{2} \mathrm{Cl}_{2}\right) \delta=159.6(\mathrm{Tz}-5 \mathrm{C}), 157.7,151.8,148.7,147.2,139.6,126.0$ 120.8 (all Ar/Py-C), 97.7, 96.9, 81.1, 79.3, 77.1, 72.0 (all Cym-C), $49.4\left(\mathrm{~N}-\mathrm{CH}_{2} \mathrm{CH}_{3}\right), \quad 38.9\left(\mathrm{~N}-\mathrm{CH}_{3}\right), \quad 31.5\left(\mathrm{CH}\left(\mathrm{CH}_{3}\right)_{2}\right), \quad 22.3$ $\left(\mathrm{CH}\left(\mathrm{CH}_{3}\right)_{2}\right), 18.6\left(\mathrm{CH}\left(\mathrm{CH}_{3}\right)_{2}\right), 15.3\left(\mathrm{~N}-\mathrm{CH}_{2} \mathrm{CH}_{3}\right)$. HRMS (ESI +) $\mathrm{m} / z$ calcd. for $\mathrm{C}_{20} \mathrm{H}_{26} \mathrm{ClN}_{4} \mathrm{Os}^{+}[\mathrm{M}]^{+}=549.1455$, found 549.1453 .

Iridium Complexes. $I r^{5}$. From $\mathbf{L}^{8}(65 \mathrm{mg})$ and $\left[\mathrm{IrCp} * \mathrm{Cl}_{2}\right]_{2}(80$ $\mathrm{mg})$. Bright-yellow solid. Yield: 63\% (0.126 mmol, $93 \mathrm{mg}) .{ }^{1} \mathrm{H}$ NMR $\left(400 \mathrm{MHz}, \mathrm{CD}_{2} \mathrm{Cl}_{2}\right) \delta=8.76(\mathrm{dt}, J=5.7,1.1 \mathrm{~Hz}, 1 \mathrm{H}, \mathrm{Py}-H), 8.13-$ $8.06(\mathrm{~m}, 2 \mathrm{H}, \mathrm{Py}-\mathrm{H}), 8.00-7.96(\mathrm{~m}, 2 \mathrm{H}, \mathrm{Ar}-\mathrm{H}), 7.67-7.61(\mathrm{~m}, 3 \mathrm{H}$, $\mathrm{Ar}-\mathrm{H}), 7.50(\mathrm{ddd}, J=6.8,5.7,2.2 \mathrm{~Hz}, 1 \mathrm{H}, \mathrm{Py}-\mathrm{H}), 4.61(\mathrm{~s}, 3 \mathrm{H}, \mathrm{N}-$ $\left.\mathrm{CH}_{3}\right), 1.42\left(\mathrm{~s}, 15 \mathrm{H}, \mathrm{Cp}^{*}-\mathrm{CH}_{3}\right) \cdot{ }^{13} \mathrm{C}$ NMR $\left(100 \mathrm{MHz}, \mathrm{CD}_{2} \mathrm{Cl}_{2}\right) \delta=$ 156.5 ( Tz-C), 153.7, 148.7, 148.5, 140.2, 138.0, 131.1, 130.0, 126.3, 125.3, 121.3 (all $\mathrm{Ar} / \mathrm{Py}-\mathrm{C}), 91.2\left(\mathrm{Cp}^{*}-\mathrm{C}\right), 39.3\left(\mathrm{~N}-\mathrm{CH}_{3}\right), 8.7$ $\left(\mathrm{Cp}^{*}-\mathrm{CH}_{3}\right.$ ). HRMS (ESI+) $\mathrm{m} / z$ calcd. for $\mathrm{C}_{24} \mathrm{H}_{27} \mathrm{ClIrN}_{4}^{+}[\mathrm{M}]^{+}=$ 599.1553, found 599.1508 .

Ir $^{6}$. From $\mathrm{L}^{9}(71 \mathrm{mg})$ and $\left[\mathrm{IrCp}^{*} \mathrm{Cl}_{2}\right]_{2}(80 \mathrm{mg})$. Bright-yellow solid. Yield: $73 \%$ (0.143 mmol, $112 \mathrm{mg}) .{ }^{1} \mathrm{H}$ NMR (400 MHz, $\left.\mathrm{CD}_{2} \mathrm{Cl}_{2}\right) \delta=8.76(\mathrm{dd}, J=5.8,0.5 \mathrm{~Hz}, 1 \mathrm{H}, \mathrm{Py}-H$ ), 8.08 (ddd, $J=7.9$, 1.6, $0.3 \mathrm{~Hz}, 1 \mathrm{H}, \mathrm{Py}-H), 8.01$ (d, $J=8.1 \mathrm{~Hz}, 1 \mathrm{H}, \mathrm{Py}-H), 7.88$ (d, $J=$ $8.9 \mathrm{~Hz}, 2 \mathrm{H}, \mathrm{Ar}-H$ ), 7.49 (ddd, $J=7.4,5.9,1.4 \mathrm{~Hz}, 1 \mathrm{H}, \mathrm{Py}-H$ ), 7.09 $(\mathrm{d}, J=7.0 \mathrm{~Hz}, 2 \mathrm{H}, \mathrm{Ar}-\mathrm{H}), 4.57\left(\mathrm{~s}, 3 \mathrm{H}, \mathrm{N}-\mathrm{CH}_{3}\right), 3.88(\mathrm{~s}, 3 \mathrm{H}, \mathrm{O}-$ $\left.\mathrm{CH}_{3}\right), 1.44\left(\mathrm{~s}, 15 \mathrm{H}, \mathrm{Cp} *-\mathrm{CH}_{3}\right) .{ }^{13} \mathrm{C}$ NMR $\left(100 \mathrm{MHz}, \mathrm{CD}_{2} \mathrm{Cl}_{2}\right) \delta=$ 161.6 ( $\mathrm{Ar}-\mathrm{C}), 156.3(\mathrm{Tz}-\mathrm{C}), 153.8,148.8,148.2,140.1,131.0$, 126.7, 126.3, 122.6, 121.0, 114.9 (all $\mathrm{Ar} / \mathrm{Py}-\mathrm{C}), 91.2\left(\mathrm{Cp}^{*}-\mathrm{CH}_{3}\right)$ $55.9\left(\mathrm{O}-\mathrm{CH}_{3}\right), 39.1\left(\mathrm{~N}-\mathrm{CH}_{3}\right), 8.8\left(\mathrm{Cp}^{*}-\mathrm{CH}_{3}\right)$. HRMS (ESI+) $\mathrm{m} / z$ calcd. for $\mathrm{C}_{25} \mathrm{H}_{29} \mathrm{ClIrN}_{4} \mathrm{O}^{+}[\mathrm{M}]^{+}=629.1659$, found 629.1616 .

$\mathbf{I r}^{7}$. From $\mathbf{L}^{10}(78 \mathrm{mg})$ and $\left[\mathrm{IrCp}^{*} \mathrm{Cl}_{2}\right]_{2}(80 \mathrm{mg})$. Bright-yellow solid. Yield: $75 \%(0.15 \mathrm{mmol}, 122 \mathrm{mg}) .{ }^{1} \mathrm{H}$ NMR $(400 \mathrm{MHz}$ 
A
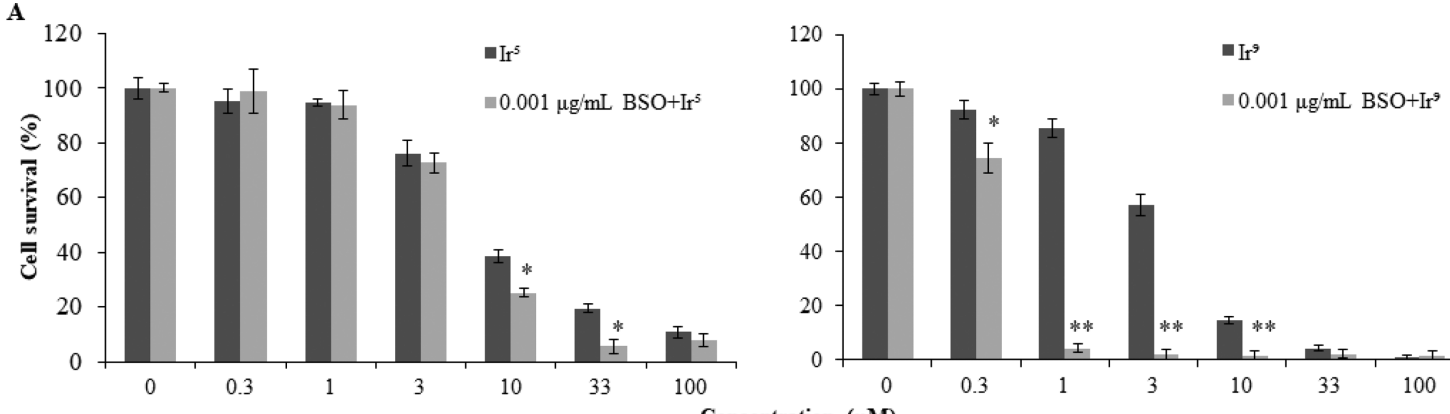

B

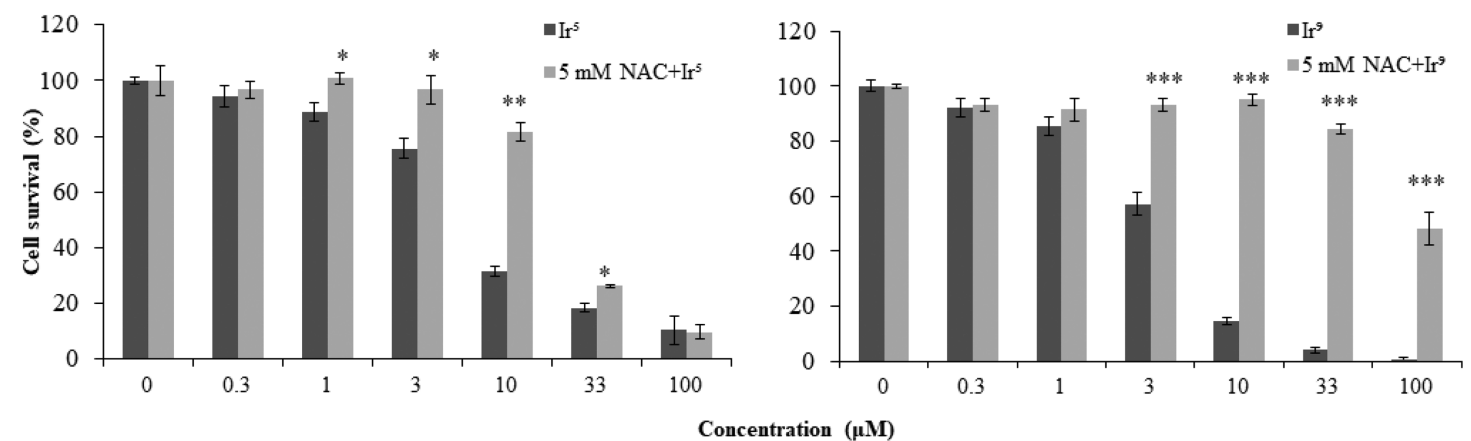

C
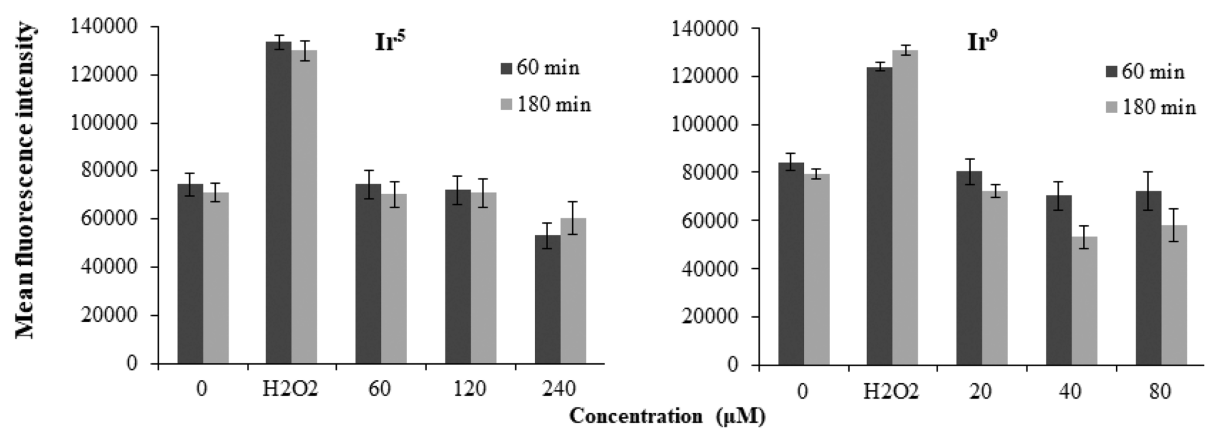

D

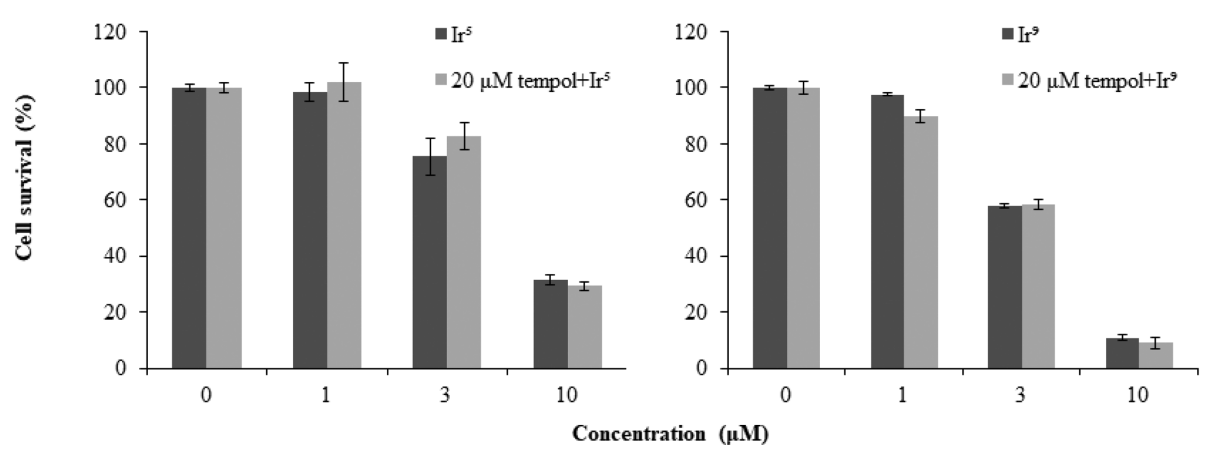

Figure 5. The role of GSH level on cell survival upon treatment with $\mathbf{I r}^{5}$ and $\mathbf{I r}^{9}$. Eight hours after seeding cells were pretreated for 16 hours with $0.001 \mu \mathrm{g} / \mathrm{mL}$ BSO (A) or $24 \mathrm{~h}$ after the seeding with $5 \mathrm{mM}$ of NAC for $2 \mathrm{~h}$ (B). Afterward different concentrations of $\mathbf{I r}^{5}$ or $\mathbf{I r}^{9}$ were added. The cell survival was determined $72 \mathrm{~h}$ later by MTT assay. Each point represents the mean \pm SD of at least three independent experiments. All data are expressed as the average percentage of survival values relative to an untreated control \pm SD or samples treated with either BSO or NAC alone. The significance in differences is indicated $\left({ }^{*} P<0.05 ; * *<0.01\right.$; $\left.* * * P<0.001\right)$. Twenty-four hours after seeding the cells were treated with different concentrations of $\mathbf{I r}^{5}$ or $\mathbf{I r}^{9}$ during either 60 or $180 \mathrm{~min} . \mathrm{H}_{2} \mathrm{O}_{2}$ treatment $(0.01 \%, 30 \mathrm{~min})$ was used as a positive control for formation of $\mathrm{ROS}(\mathrm{C})$. Each point represents the mean \pm SD of two independent measurements performed in quadruplicates. Twenty-four hours after seeding cells were pretreated for $2 \mathrm{~h}$ with $20 \mu \mathrm{M}$ tempol. Afterward different concentrations of $\mathbf{I r}^{5}$ or $\mathbf{I r}^{9}$ were added. The cell survival was determined $72 \mathrm{~h}$ later by MTT assay. (D) Each point represents the mean \pm SD of at least three independent experiments. All data are expressed as the average percentage of survival values relative to an untreated control $\pm \mathrm{SD}$ or samples treated with tempol alone.

$\left.\mathrm{CD}_{2} \mathrm{Cl}_{2}\right) \delta=8.77(\mathrm{ddd}, J=5.7,1.5,0.7 \mathrm{~Hz}, 1 \mathrm{H}, \mathrm{Py}-H), 8.21(\mathrm{~d}, J=$ $8.3 \mathrm{~Hz}, 2 \mathrm{H}, \mathrm{Ar}-\mathrm{H}$ ), 8.10 (ddd, $J=8.0,1.4,0.3 \mathrm{~Hz}, 1 \mathrm{H}, \mathrm{Py}-\mathrm{H}$ ), 8.04 $(\mathrm{td}, J=8.1,1.4 \mathrm{~Hz}, 1 \mathrm{H}, \mathrm{Py}-\mathrm{H}), 7.91(\mathrm{~d}, J=8.8 \mathrm{~Hz}, 2 \mathrm{H}, \mathrm{Ar}-H), 7.51$ (ddd, $J=6.0,1.4,0.3 \mathrm{~Hz}, 1 \mathrm{H}, \mathrm{Py}-\mathrm{H}), 4.61\left(\mathrm{~s}, 3 \mathrm{H}, \mathrm{N}-\mathrm{CH}_{3}\right), 1.43(\mathrm{~s}$, $\left.15 \mathrm{H}, \mathrm{Cp} *-\mathrm{CH}_{3}\right) \cdot{ }^{13} \mathrm{C}$ NMR $\left(100 \mathrm{MHz}, \mathrm{CD}_{2} \mathrm{Cl}_{2}\right) \delta=157.2(\mathrm{Tz}-\mathrm{C})$, 153.8, 148.8, 148.6, 140.7, 140.2 (all Ar/Py-C), 132.9 (q, $J=33 \mathrm{~Hz}$, 
$\mathrm{Ar}-\mathrm{C}), 127.2$ (q, $J=4 \mathrm{~Hz}, \mathrm{Ar}-\mathrm{C}), 126.4,126.1$ (all Ar/Py-C), 123.5 $\left(\mathrm{q}, J=273 \mathrm{~Hz}, \mathrm{CF}_{3}\right), 121.2(\mathrm{Ar} / \mathrm{Py}-\mathrm{C}), 91.4\left(\mathrm{Cp}^{*}-\mathrm{C}\right), 39.4(\mathrm{~N}-$ $\left.\mathrm{CH}_{3}\right), 8.7\left(\mathrm{Cp}^{*}-\mathrm{CH}_{3}\right)$. HRMS (ESI+) $\mathrm{m} / z$ calcd. for $\mathrm{C}_{25} \mathrm{H}_{26} \mathrm{ClF}_{3} \mathrm{IrN}_{4}^{+}[\mathrm{M}]^{+}=667.1427$, found 667.1391.

Ir $^{9}$. From L $\mathrm{L}^{12}(82 \mathrm{mg})$ and $\left[\operatorname{Ir}\left(\mathrm{Cp}^{*}\right) \mathrm{Cl}_{2}\right]_{2}(80 \mathrm{mg})$. Yellow solid. Yield: $75 \%(0.15 \mathrm{mmol}, 124 \mathrm{mg}) .{ }^{1} \mathrm{H}$ NMR $\left(400 \mathrm{MHz}, \mathrm{CD}_{2} \mathrm{Cl}_{2}\right) \delta=$ 8.79-8.71 (m, 1H, Py-H), 8.14-8.08 (m, $1 \mathrm{H}, \mathrm{Py}-H)$, 8.08-8.04 $(\mathrm{m}, 1 \mathrm{H}, \mathrm{Py}-\mathrm{H}), 7.60(\mathrm{t}, J=8.0 \mathrm{~Hz}, 1 \mathrm{H}, \mathrm{Ar}-\mathrm{H}), 7.55-7.52(\mathrm{~m}, 1 \mathrm{H}$, Py-H), 7.44-7.39 (m, 2H, Ar-H), 4.61 (s, 3H, N-CH $), 3.17$ (sept, $\left.J=6.8 \mathrm{~Hz}, 1 \mathrm{H}, \mathrm{CH}\left(\mathrm{CH}_{3}\right)_{2}\right), 2.35$ (sept, $\left.J=6.8 \mathrm{~Hz}, 1 \mathrm{H}, \mathrm{CH}\left(\mathrm{CH}_{3}\right)_{2}\right)$, $1.41\left(\mathrm{~s}, 15 \mathrm{H}, \mathrm{Cp} *-\mathrm{CH}_{3}\right), 1.34\left(\mathrm{~d}, \mathrm{~J}=6.8 \mathrm{~Hz}, 3 \mathrm{H}, \mathrm{CH}\left(\mathrm{CH}_{3}\right)_{2}\right), 1.27$ $\left(\mathrm{d}, J=6.8 \mathrm{~Hz}, 3 \mathrm{H}, \mathrm{CH}\left(\mathrm{CH}_{3}\right)_{2}\right), 1.19\left(\mathrm{~d}, J=6.8 \mathrm{~Hz}, 3 \mathrm{H}, \mathrm{CH}\left(\mathrm{CH}_{3}\right)_{2}\right)$, $0.78\left(\mathrm{~d}, J=6.8 \mathrm{~Hz}, 3 \mathrm{H}, \mathrm{CH}\left(\mathrm{CH}_{3}\right)_{2}\right) .{ }^{13} \mathrm{C} \mathrm{NMR}\left(100 \mathrm{MHz}, \mathrm{CD}_{2} \mathrm{Cl}_{2}\right)$ $\delta=158.4(\mathrm{Tz}-\mathrm{C}), 153.3,149.6,148.7,146.8,146.4,139.9,134.4$, 132.1, 126.5, 124.6, 124.4, 121.2 (all $\mathrm{Ar}-\mathrm{C}$ ), $91.1\left(\mathrm{Cp}^{*}-\mathrm{C}\right), 39.4$ $\left(\mathrm{N}-\mathrm{CH}_{3}\right), 29.0\left(\mathrm{CH}\left(\mathrm{CH}_{3}\right)_{2}\right), 27.9\left(\mathrm{CH}\left(\mathrm{CH}_{3}\right)_{2}\right), 27.0\left(\mathrm{CH}\left(\mathrm{CH}_{3}\right)_{2}\right)$, $25.3\left(\mathrm{CH}\left(\mathrm{CH}_{3}\right)_{2}\right), 21.7\left(\mathrm{CH}\left(\mathrm{CH}_{3}\right)_{2}\right), 21.6\left(\mathrm{CH}\left(\mathrm{CH}_{3}\right)_{2}\right), 8.8\left(\mathrm{Cp}^{*}-\right.$ $\mathrm{CH}_{3}$ ). HRMS (ESI+) $\mathrm{m} / z$ calcd. for $\mathrm{C}_{30} \mathrm{H}_{39} \mathrm{ClIrN}_{4}{ }^{+}[\mathrm{M}]^{+}=683.2492$, found 683.2464 .

Biology. Cell Culture. Human cervical carcinoma HeLa and laryngeal carcinoma HEp2 cells were obtained from cell culture bank (GIBCO BRL-Invitrogen, USA). Large cell lung carcinoma H460 and colorectal carcinoma HCT-116 cell lines were obtained from American Type Culture Collection (ATCC, USA). Human ovarian cancer cell line MES-OV was obtained from Prof. Sikic group (Stanford University, USA). Normal human skin keratinocyte line was obtained from the foreskin of healthy boys, aged 3-8 years. Foreskin samples were noninflamed and the children were free of any therapy at least 1 month before the surgery. ${ }^{27}$ The cells were obtained at the Neurochemical Laboratory, Department of Chemistry and Biochemistry, School of Medicine, University of Zagreb. All cell lines were grown as a monolayer culture in Dulbecco's modified Eagle's medium (DMEM; Sigma-Aldrich, USA), supplemented with $10 \%$ fetal bovine serum (FBS; Sigma-Aldrich) in a humidified atmosphere of $5 \% \mathrm{CO}_{2}$ at $37{ }^{\circ} \mathrm{C}$ and were subcultured every 3-4 days.

Cytotoxicity Assay. Cytotoxic activity of organometallic complexes was determined by MTT assay ${ }^{28}$ adjusted accordingly. In short, the cells were seeded into 96-well tissue culture plates. The next day different concentrations of compounds were added to each well in quadruplicate. Upon $72 \mathrm{~h}$ incubation at $37{ }^{\circ} \mathrm{C}$, the medium was aspirated and the 3-(4,5-dimethylthiazol-2-yl)-2,5-diphenyltetrazolium bromide (MTT) dye (Sigma-Aldrich) was added. Three hours later, formazan crystals were dissolved in DMSO, the plates were mechanically agitated for $5 \mathrm{~min}$, and the optical density at $545 \mathrm{~nm}$ was determined on a microtiter plate reader (Awareness Technology Inc., USA). The cytotoxicity was expressed either as $\mathrm{IC}_{20}, \mathrm{IC}_{50}$, or $\mathrm{IC}_{80}$ (survival rate 80,50 , and $20 \%$ compared to nontreated, control cells, which survival was set at $100 \%$ ).

Cell Cycle and Cell Death Analysis. HeLa cells were seeded into tissue culture plates and treated with different concentrations of compounds for the indicated time. Thereafter, both adherent and floating cells were collected, washed with PBS and fixed overnight in $96 \%$ ethanol at $-20^{\circ} \mathrm{C}$. Fixed cells were treated with RNase A (0.1 $\mathrm{mg} / \mathrm{mL}$, Sigma-Aldrich) for $30 \mathrm{~min}$ in water bath $\left(37^{\circ} \mathrm{C}\right)$ and afterward stained with propidium iodide $(50 \mu \mathrm{g} / \mathrm{mL}$, Sigma-Aldrich $)$ for $30 \mathrm{~min}$ in the dark. The DNA content was analyzed on flow cytometer (FACS Calibur, Becton Dickinson, USA). Data were analyzed for cell cycle distribution in FlowLogic software (Inivai Technologies, Australia) using cell cycle specific gating protocol and Watson pragmatic convolution.

In order to determine the type of cell death, HeLa cells were treated with different concentrations of investigated compounds. After specific time, both adherent and floating cells were collected, washed two times with PBS and stained with Annexin V and/or PI (propidium iodide) according to the producer's protocol (ThermoFisher Scientific, USA). The DNA content and Annexin V fluorescence were analyzed by flow cytometry (FACS Calibur, Becton Dickinson). Data were analyzed with FlowLogic software (Inivai Technologies, Australia) using specific gating protocol. After determination of protein concentration by Bradford analysis, ${ }^{29}$ the
$30 \mu \mathrm{g}$ of whole cell proteins were loaded on SDS polyacrylamide gel. Well accepted marker of apoptosis, cleaved PARP, ${ }^{14}$ was determined by using specific anti-PARP antibody (Cell Signaling Technology, USA). As internal loading controls ERK1/2 or ERK2 were used (Santa Cruz Technology, USA). In addition, the activities of caspases 3 and 7 were determined. Cells were seeded into tissue culture plates and after 1 day treated with different concentrations of investigated compounds. Upon $72 \mathrm{~h}$ incubation Caspase Glo 3/7 Mix (Promega, USA) was added, and the producer's protocol was followed. Luminometric signal was read on Fluoroskan Ascent FL (Thermo Fisher Scientific, USA) spectrometer. The possible role of autophagy and necroptosis as cell death models was checked as previously described. ${ }^{24}$

Accumulation of Iridium in the Cells. The total accumulation of iridium was measured as described previously for measurement of total cell platination ${ }^{21}$ with modifications. In short, upon treatment of cells with different concentrations of $\mathbf{I r}^{5}$ or $\mathbf{I r}^{9}$ during $3 \mathrm{~h}$, the cells were rinsed with ice-cold PBS and harvested into $10 \mathrm{~mL}$ of ice-cold PBS using a rubber policeman. After centrifugation, the cells were resuspended in PBS, an aliquot was used for determination of cell number. and the rest was digested in $70 \%$ nitric acid. Cell lysates were heated for $2 \mathrm{~h}$ at $75{ }^{\circ} \mathrm{C}$, diluted in $5 \%$ nitric acid and assayed for iridium content. The amount of iridium was measured by a validated high-resolution inductively coupled plasma mass spectrometry (HR ICPMS) using the Element 2 (Thermo Finnigan, Germany). Calibration standards were prepared from single-element standard diluted in hydrochloric acid and water $(1000 \mu \mathrm{g} / \mathrm{mL}$; Agilent, USA).

The Role of Glutathione in Cell Response to $1 r^{5}$ and $I r^{9}$. The role of glutathione (GSH) in cell response to $\mathbf{I r}^{5}$ and $\mathbf{I r}^{9}$ was investigated by MTT assay by pretreatment of cells with specific inhibitor of GSH synthesis, buthionine sulfoximine (BSO) or precursor in GSH synthesis $\mathrm{N}$-acetyl-cysteine (NAC). To examine the influence of GSH depletion on response of HeLa cells to selected compounds, $8 \mathrm{~h}$ after the seeding the cells were pretreated with $0.001 \mu \mathrm{g} / \mathrm{mL}$ of BSO. Sixteen hours later the cells were treated with different concentrations of either $\mathbf{I r}^{\mathbf{5}}$ or $\mathbf{I r}^{9}$, and the cytotoxicity effect was determined $72 \mathrm{~h}$ later. To determine the influence of increase of GSH synthesis on cells response to selected compounds, $5 \mathrm{mM} \mathrm{NAC}$ was added $2 \mathrm{~h}$ before treatment of cells with different concentrations of either $\mathbf{I r}^{5}$ or $\mathbf{I r}^{9}$. Generation of ROS was determined using the fluorescent dye 5-(and6)-chloromethyl-29,79-dichlorodihydrofluorescein diacetate, acetyl ester (CM- $\left.\mathrm{H}_{2} \mathrm{DCFDA}\right)$ (Life Technologies, USA) according to the previously described protocol. ${ }^{19}$ Possible role of ROS in induction of cells death was additionally checked by $2 \mathrm{~h}$ pretreatment with $20 \mu \mathrm{M}$ tempol, well accepted antioxidant ${ }^{30}$ and then treated with different concentrations of either $\mathbf{I r}^{5}$ or $\mathbf{I r}^{9}$. The cytotoxicity effect was determined $72 \mathrm{~h}$ later by MTT assay.

Statistical Analysis. Data were analyzed by unpaired Student's $t$ test and expressed as a mean \pm standard error of the mean. Data were considered significant when $P$ values were lower than 0.05 , and in the figures, these are designated as $* P<0.05, * * P<0.01$, or $* * * P<$ 0.001 . Experiments were performed in triplicate and repeated at least twice.

\section{ASSOCIATED CONTENT}

\section{S Supporting Information}

The Supporting Information is available free of charge on the ACS Publications website at DOI: 10.1021/acs.organomet.9b00327.

Crystallographic details, ${ }^{1} \mathrm{H}$ and ${ }^{13} \mathrm{C}$ NMR spectra for all new compounds (PDF)

\section{Accession Codes}

CCDC 1044233-1044236 and 973835 contain the supplementary crystallographic data for this paper. These data can be obtained free of charge via www.ccdc.cam.ac.uk/data_request/ cif, or by emailing data_request@ccdc.cam.ac.uk, or by 
contacting The Cambridge Crystallographic Data Centre, 12 Union Road, Cambridge CB2 1EZ, UK; fax: +44 1223336033.

\section{AUTHOR INFORMATION}

\section{Corresponding Authors}

*E-mail: biprajit.sarkar@fu-berlin.de (B.S).

*E-mail: anamaria.brozovic@irb.hr (A.B.).

*E-mail: janez.kosmrlj@fkkt.uni-lj.si (J.K.).

ORCID $\odot$

Stephan Hohloch: 0000-0002-5353-0801

Biprajit Sarkar: 0000-0003-4887-7277

Janez Košmrlj: 0000-0002-3533-0419

\section{Author Contributions}

\# JK and $\mathrm{AB}$ contributed equally.

\section{Notes}

The authors declare no competing financial interest.

\section{ACKNOWLEDGMENTS}

The authors acknowledge the financial support from the Slovenian Research Agency (Research Core Funding Grant P1-0230 and Projects J1-8147 and J1-9166), the Croatian Science Foundation (HrZZ, project number IP-2016-061036), Croatian-Slovenian bilateral project BI-HR/18-19-028, and the Freie Universität Berlin. Financial support from Joint PPP-Project DAAD-ARRS BI-DE/17-19-9 funded by the DAAD through funds from the Bundesministerium fer Bildung und Forschung (BMBF) is also acknowledged.

\section{REFERENCES}

(1) Peters, G. J.; Raymond, E. Contemporary reviews on cancer treatment. Cancer Chemother. Pharmacol. 2016, 77, 3-4.

(2) Dasari, S.; Tchounwou, P. B. Cisplatin in cancer therapy: Molecular mechanisms of action. Eur. J. Pharmacol. 2014, 740, 364378.

(3) Gasser, G.; Ott, I.; Metzler-Nolte, N. Organometallic anticancer compounds. J. Med. Chem. 2011, 54, 3-25.

(4) (a) Schuster, O.; Yang, L.; Raubenheimer, H. G.; Albrecht, M. Beyond conventional $\mathrm{N}$-heterocyclic carbenes: abnormal, remote, and other classes of NHC ligands with reduced heteroatom stabilization. Chem. Rev. 2009, 109, 3445-3478. (b) Crowley, J. D.; Lee, A.-L.; Kilpin, K. J. 1,3,4-Trisubtituted-1,2,3-Triazol-5-ylidene 'Click' Carbene Ligands: Synthesis, Catalysis and Self-Assembly. Aust. J. Chem. 2011, 64, 1118-1132. (c) Bernet, L.; Lalrempuia, R.; Ghattas, W.; Mueller-Bunz, H.; Vigara, L.; Llobet, A.; Albrecht, M. Tunable singlesite ruthenium catalysts for efficient water oxidation. Chem. Commun. 2011, 47, 8058-8060. (d) Donnelly, K. F.; Petronilho, A.; Albrecht, M. Application of 1,2,3-triazolylidenes as versatile NHC-type ligands: synthesis, properties, and application in catalysis and beyond. Chem. Commun. 2013, 49, 1145-1159. (e) Woods, J. A.; Lalrempuia, R.; Petronilho, A.; McDaniel, N. D.; Müller-Bunz, H.; Albrecht, M.; Bernhard, S. Carbene iridium complexes for efficient water oxidation: scope and mechanistic insights. Energy Environ. Sci. 2014, 7, 23162328. (f) Schweinfurth, D.; Hettmanczyk, L.; Suntrup, L.; Sarkar, B. Metal Complexes of Click-Derived Triazoles and Mesoionic Carbenes: Electron Transfer, Photochemistry, Magnetic Bistability, and Catalysis. Z. Anorg. Allg. Chem. 2017, 643, 554-584. (g) Guisado-Barrios, G.; Soleilhavoup, M.; Bertrand, G. 1H-1,2,3Triazol-5-ylidenes: Readily Available Mesoionic Carbenes. Acc. Chem. Res. 2018, 51, 3236-3244.

(5) Vivancos, A.; Segarra, C.; Albrecht, M. Mesoionic and Related Less Heteroatom-Stabilized N-Heterocyclic Carbene Complexes: Synthesis, Catalysis, and Other Applications. Chem. Rev. 2018, 118, 9493-9586.

(6) (a) Kilpin, K. J.; Crot, S.; Riedel, T.; Kitchen, J. A.; Dyson, P. J. Ruthenium(II) and osmium(II) 1,2,3-Triazolylidene Organometal- lics: A Preliminary Investigation into the Biological Activity of "Click" Carbene Complexes. Dalton Trans 2014, 43, 1443-1448. (b) Lee, J.Y.; Lee, J.-Y.; Chang, Y.; Hu, C.; Wang, N. M.; Lee, H. M. Palladium Complexes with Tridentate N-Heterocyclic Carbene Ligands: Selective "Normal" and "Abnormal" Bindings and Their Anticancer Activities. Organometallics 2015, 34, 4359-4368. (c) Vanicek, S.; Podewitz, M.; Stubbe, J.; Schulze, D.; Kopacka, H.; Wurst, K.; Muller, T.; Lippmann, P.; Haslinger, S.; Schottenberger, H.; Liedl, K. R.; Ott, I.; Sarkar, B.; Bildstein, B. Highly Electrophilic, Catalytically Active and Redox-Responsive Cobaltoceniumyl and Ferrocenyl Triazolylidene Coinage Metal Complexes. Chem. - Eur. J. 2018, 24, 3742-3753. (d) Aucamp, D.; Kumar, S. V.; Liles, D. C.; Fernandes, M. A.; Harmse, L.; Bezuidenhout, D. I. Synthesis of heterobimetallic gold(I) ferrocenyl-substituted 1,2,3-triazol-5-ylidene complexes as potential anticancer agents. Dalton Trans 2018, 47, 16072-16081.

(7) Steiner, I.; Stojanovic, N.; Bolje, A.; Brozovic, A.; Polancec, D.; Ambriovic-Ristov, A.; Stojkovic, M. R.; Piantanida, I.; Eljuga, D.; Kosmrlj, J.; Osmak, M. Discovery of 'click' 1,2,3-triazolium salts as potential anticancer drugs. Radiol. Oncol. 2016, 50, 280-288.

(8) (a) Bolje, A.; Hohloch, S.; Urankar, D.; Pevec, A.; Gazvoda, M.; Sarkar, B.; Košmrlj, J. Exploring the Scope of Pyridyl- and PicolylFunctionalized 1,2,3-Triazol-5-ylidenes in Bidentate Coordination to Ruthenium(II) Cymene Chloride Complexes. Organometallics 2014, 33, 2588-2598. (b) Bolje, A.; Hohloch, S.; van der Meer, M.; Košmrlj, J.; Sarkar, B. RuII, OsII, and IrIII Complexes with Chelating Pyridyl-Mesoionic Carbene Ligands: Structural Characterization and Applications in Transfer Hydrogenation Catalysis. Chem. - Eur. J. 2015, 21, 6756-6764. (c) Hohloch, S.; Kaiser, S.; Dücker, F. L.; Bolje, A.; Maity, R.; Košmrlj, J.; Sarkar, B. Catalytic oxygenation of sp3 "C-H" bonds with $\mathrm{Ir}(\mathrm{III})$ complexes of chelating triazoles and mesoionic carbenes. Dalton Trans 2015, 44, 686-693. (d) Bolje, A.; Hohloch, S.; Košmrlj, J.; Sarkar, B. RuII, IrIII and OsII mesoionic carbene complexes: efficient catalysts for transfer hydrogenation of selected functionalities. Dalton Trans 2016, 45, 15983-15993. (e) Gazvoda, M.; Virant, M.; Pevec, A.; Urankar, D.; Bolje, A.; Kočevar, M.; Košmrlj, J. A mesoionic bis(Py-tzNHC) palladium(II) complex catalyses "green" Sonogashira reaction through an unprecedented mechanism. Chem. Commun. 2016, 52, 1571-1574.

(9) Bolje, A.; Košmrlj, J. A Selective Approach to Pyridine Appended 1,2,3-Triazolium Salts. Org. Lett. 2013, 15, 5084-5087.

(10) Bolje, A.; Urankar, D.; Košmrlj, J. Synthesis and NMR Analysis of 1,4-Disubstituted 1,2,3-Triazoles Tethered to Pyridine, Pyrimidine, and Pyrazine Rings. Eur. J. Org. Chem. 2014, 2014, 8167-8181.

(11) Burja, B.; Cimbora-Zovko, T.; Tomić, S.; Jelusić, T.; Kočevar, M.; Polanc, S.; Osmak, M. Pyrazolone-fused combretastatins and their precursors: synthesis, cytotoxicity, antitubulin activity and molecular modeling studies. Bioorg. Med. Chem. 2010, 18, 2375-2387.

(12) Cimbora-Zovko, T.; Brozovic, A.; Piantanida, I.; Fritz, G.; Virag, A.; Alič, B.; Majce, V.; Kočevar, M.; Polanc, S.; Osmak, M. Synthesis and biological evaluation of 4-nitro-substituted 1,3-diaryltriazenes as a novel class of potent antitumor agents. Eur. J. Med. Chem. 2011, 46, 2971-2983.

(13) Branzei, D.; Foiani, M. Regulation of DNA repair throughout the cell cycle. Nat. Rev. Mol. Cell Biol. 2008, 9, 297-308.

(14) Boulares, A. H.; Yakovlev, A. G.; Ivanova, V.; Stoica, B. A.; Wang, G.; Iyer, S.; Smulson, M. Role of poly(ADP-ribose)polymerase (PARP) cleavage in apoptosis. Caspase 3-resistant PARP mutant increases rates of apoptosis in transfected cells. J. Biol. Chem. 1999, 274, 22932-22940.

(15) Chaitanya, G.; Alexander, J. S; Babu, P. PARP-1 cleavage fragments: signatures of cell-death proteases in neurodegeneration. Cell Commun. Signaling 2010, 8, 2-11.

(16) Kocaturk, N. M.; Akkoc, Y.; Kig, C.; Bayraktar, O.; Gozuacik, D.; Kutlu, O. Autophagy as a molecular target for cancer treatment. Eur. J. Pharm. Sci. 2019, 134, 116-137.

(17) Vandenabeele, P.; Grootjans, S.; Callewaert, N.; Takahashi, N. Necrostatin-1 blocks both RIPK1 and IDO: consequences for the study of cell death in experimental disease models. Cell Death Differ. 2013, 20, 185-187. 
(18) Circu, M. L.; Aw, T. Y. Reactive oxygen species, cellular redox systems, and apoptosis. Free Radical Biol. Med. 2010, 48, 749-762.

(19) Ramsay, E. E.; Dilda, P. J. Glutathione S-conjugates as prodrugs to target drug-resistant tumors. Front. Pharmacol. 2014, 5, 181.

(20) Martin-Kleiner, I.; Bombek, S.; Košmrlj, J.; Cupić, B.; CimboraZovko, T.; Jakopec, S.; Polanc, S.; Osmak, M.; Gabrilovac, J. Selective cytotoxicity of diazenecarboxamides towards human leukemic cell lines. Toxicol. In Vitro 2007, 21, 1453-1459.

(21) Brozovic, A.; Vuković, L.; Polančec, D. S.; Arany, I.; Köberle, B.; Fritz, G.; Fiket, Ž.; Majhen, D.; Ambriović-Ristov, A.; Osmak, M. Endoplasmic reticulum stress is involved in the response of human laryngeal carcinoma cells to Carboplatin but is absent in Carboplatinresistant cells. PLoS One 2013, 8, No. e76397.

(22) Grienke, U.; Radić Brkanac, S.; Vujčić, V.; Urban, E.; Ivanković, S.; Stojković, R.; Rollinger, J. M.; Kralj, J.; Brozovic, A.; Radić Stojkovic, M. Biological Activity of Flavonoids and Rare Sesquiterpene Lactones Isolated From Centaurea ragusina L. Front. Pharmacol. 2018, 9, 972.

(23) Aquilano, K.; Baldelli, S.; Ciriolo, M. R. Glutathione: new roles in redox signaling for an old antioxidant. Front. Pharmacol. 2014, 5, 196.

(24) Pernar, M.; Kokan, Z.; Kralj, J.; Glasovac, Z.; Tumir, L. M.; Piantanida, I.; Eljuga, D.; Turel, I.; Brozovic, A.; Kirin, S. I. Organometallic ruthenium(II)-arene complexes with triphenylphosphine amino acid bioconjugates: Synthesis, characterization and biological properties. Bioorg. Chem. 2019, 87, 432-446.

(25) Huang, W.; Zhang, R.; Zou, G.; Tang, J.; Sun, J. An iodide/ anion exchange route to benzimidazolylidene silver complexes from benzimidazolium iodide: Crystal structures of N,N'-dibutylbenzimidazolylidene silver chloride, bromide, cyanide and nitrate. $J$. Organomet. Chem. 2007, 692, 3804-3809.

(26) Sheldrick, G. M. SHELX-97, Program for Crystal Structure Refinement; Göttingen: Germany, 1997.

(27) Gabrilovac, J.; Cupić, B.; Breljak, D.; Zekusić, M.; Boranic, M. Expression of CD13/aminopeptidase N and CD10/neutral endopeptidase on cultured human keratinocytes. Immunol. Lett. 2004, 91, 3947.

(28) Mickisch, G.; Fajta, S.; Keilhauer, G.; Schlick, E.; Tschada, R.; Alken, P. Chemosensitivity testing of primary human renal cell carcinoma by a tetrazolium based microculture assay (MTT). Urol. Res. 1990, 18, 131-136.

(29) Bradford, M. M. A rapid and sensitive method for the quantitation of microgram quantities of protein utilizing the principle of protein-dye binding. Anal. Biochem. 1976, 72, 248-254.

(30) Wilcox, C. S. Effects of tempol and redox-cycling nitroxides in models of oxidative stress. Pharmacol. Ther. 2010, 126, 119-145. 